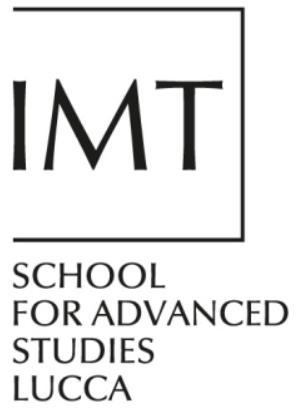

\#1

2022

IMT LUCCA EIC WORKING PAPER

SERIES 1

January 2022

\title{
The Effect of Short-Term Rentals on Local Consumption Amenities: Evidence from Madrid
}

\section{Alberto Hidalgo}

IMT School for Advanced Studies Lucca

Complutense University of Madrid

\section{Massimo Riccaboni}

IMT School for Advanced Studies Lucca

\section{Francisco J. Velázquez}

Complutense University of Madrid 


\title{
The Effect of Short-Term Rentals on Local Consumption Amenities: Evidence from Madrid*
}

\author{
Alberto Hidalgo ${ }^{\mathrm{a}, \mathrm{b} \dagger}$ Massimo Riccaboni ${ }^{\mathrm{a}}$ Francisco J. Velázquez ${ }^{\mathrm{b}}$ \\ ${ }^{a} I M T$ School for Advanced Studies Lucca, Italy \\ ${ }^{b}$ Complutense University of Madrid, Spain
}

This version: January 2022

\begin{abstract}
This paper investigates the impact of the arrival of Airbnb on the local consumption amenities in Madrid. We exploit the exogenous variation created by the timing and the unequal distribution of Airbnb listings across the urban geography to identify its effects on food and beverage establishments. Using an instrumental variable strategy, we find positive local effects on both the number of restaurants and their employees: an increase in ten Airbnb rooms in a given census tract translates into one more restaurant, and the same increase in a given neighborhood generates nine new tourist-related employees. The results are robust to sample composition, spatial spillovers and alternative measures of local consumption amenities. This paper contributes to the literature on the economic impacts of the platform economy on urban areas by providing evidence of positive economic externalities from short-term rentals.
\end{abstract}

Keywords: Consumption amenities, Short-term rentals, Tourism JEL Classification: R10, R23, Z32

*The authors are grateful for comments and suggestions received from participants at the Spanish section: XLVI International Conference on Regional Science 2021, the 46th Symposium of the Spanish Economic Association and the internal seminar GRIPICO at the Complutense University of Madrid. Especially thanks to Francesco Serti at the IMT School for Advanced Studies Lucca for his valuable suggestions.

†alberto.hidalgo@imtlucca.it. Laboratory for the Analysis of Complex Economic Systems, IMT School for Advanced Studies, piazza San Francesco 19 - 55100 Lucca, Italy. 


\section{Introduction}

The economic landscape in urban areas is rapidly changing as peer-to-peer $(\mathrm{P} 2 \mathrm{P})$ accommodation platforms enter the cities (Ferreri and Sanyal, 2018). In a short time, Airbnb, the leader in the sector, has grown from a few thousand properties in 2009 to over seven million in 2020 in more than 100,000 cities worldwide ${ }^{1}$. The explosive increase of short-term rentals in urban areas has spurred a vigorous debate about its economic impact: several studies have pointed out its deleterious effects on the housing market by increasing housing prices and rents (Garcia-López et al., 2020; Barron et al., 2021; Franco and Santos, 2021), the negative impact on hotel performance (Zervas et al., 2017; Schaefer and Tran, 2021) and the welfare impact on residents and tourists (Farronato and Fradkin, 2018; Almagro and Dominguez-Iino, 2019; CalderWang, 2019).

As short-term rental platforms diffuse, it is crucial to study their effect on the local economy, particularly their potentially uneven consequences across the urban geography. Since tourists are consumers with different needs and tastes, their arrival may change the economic activities around the new establishments. As short-term residents substitute long-term residents, the Airbnb-induced demand increases, potentially impacting stores locally. If, as Airbnb claims, guests prefer staying around and consuming near their listings, the arrival of these new temporal residents may represent a positive externality, leading to an increase in the demand for local consumption amenities like restaurants, coffee shops and other retail services. This effect gains special relevance due to the unequal distribution of $\mathrm{P} 2 \mathrm{P}$ accommodations across the urban geography: unlike the traditional accommodation industry, short-term rentals spread across the city, therefore, redistributing the economic impact of tourism across the urban geography. This new form of tourist accommodation could have the capacity to expand the benefits of tourist activities beyond the more traditionally touristic areas. Therefore, these effects could justify the policies undertaken recently by local authorities to restrain short-term rental activity in the city center but allow them to operate in peripheral areas.

To analyze the impact of short-term rentals on tourism-related activities, we focus on how Airbnb's arrival has fostered Madrid's food and beverage establishments. Four

\footnotetext{
${ }^{1}$ See https://news.airbnb.com/about-us/
} 
conditions allow us to pinpoint the effect of short-term rentals on local consumption amenities: (i) Short-term rentals are more dispersed than traditional accommodations which are concentrated in the city center. Local planning ordinances restrict the location of traditional accommodations whereas short-term rentals can freely expand in already existing dwellings across the city. The possibility to bring visitors to nontouristic areas allows us to disentangle Airbnb's effect from other accommodations; (ii) The rapid diffusion of Airbnb. The flexibility and absence of regulation have led to a sudden increase of those accommodations, unthinkable for other regulated accommodation types; (iii) Food and beverage establishments quickly react to changes in the local demand due to low startup cost; (iv) As hotel customers, Airbnb users are likely to spend a large share of the time budget in the immediate vicinity of the accommodation (Shoval et al., 2011). Hence, Airbnb is expected to transform the surrounding area to meet new customers' needs.

In this study, we introduce a novel methodological approach to exploit the exogenous variation created by the unequal entry of Airbnb across the Madrid geography. To measure the impact of Airbnb on local consumption amenities, we use a Bartiklike instrumental variable (IV) approach, exploiting the number of rented houses in 2011 (before the Airbnb entry in Madrid) and the number of worldwide Airbnb Google searches as an instrument for the short-term rentals activity. Our IV approach relies on the importance of the stock of local supply rented houses before the Airbnb entry to explain the increase in the number of short-term rentals afterward. We exploit the sharp geographic and temporal variation in the availability of short-term rentals, using the census tracts and the neighborhoods as our main geographical units of analysis.

The main results show that the entry of Airbnb has positively impacted both the employment and the number of food and beverage establishments: an increase in ten Airbnb rooms in a given census tract translates into one more restaurant. The same increase in a given neighborhood generates nine new tourist-related employees. Interestingly, Airbnb has a much stronger impact on local consumption amenities in less touristic areas, reinforcing the idea that peer-to-peer accommodations help to redistribute tourism consumption over the city. Finally, we unveil the heterogeneous impact of Airbnb on local consumption amenities, identifying the restaurants and the coffees as the main activities benefited by the short-term rentals disruption. We find no evi- 
dence of pre-trends and our results are robust to sample composition, spatial spillovers and alternative measures of local consumption activities.

Overall, we make four contributions. First, we identify positive local effects on the food and beverage sector derived from the short-term rental activity. We have access to a quarterly finer-grained data set for the universe of all economic activities in Madrid from March 2014 to October 2018. The richness of our data allows us to identify areas where Airbnb enters by using the smaller geographical unit of analysis available: census tracts. Using a narrow geographic unit of analysis help to overcome the problems of heterogeneity within larger spatial units such as ZIP codes and neighborhoods.

Second, we evaluate the heterogeneous effects of P2P accommodations across food and beverage establishments typologies identifying which type of food and beverage establishments cater to potential Airbnb users. Moreover, we decompose the overall Airbnb-induced employment effect between the intensive and the extensive margin, showing that the positive effects extend also to incumbents.

Third, we contribute a new Bartik-like instrument to solve for the endogeneity in the Airbnb activity variable: the interaction between the number of rented houses for each census tract previous to the Airbnb arrival and the worldwide Airbnb Google searches.

Fourth, this is the first study that analyses the Airbnb economic spillovers effect in an European city $^{2}$. This is of special interest since the distinction between commercial and residential areas is more nuanced in European urban areas than in the US, despite the fact that the difference is reducing over time (Gordon and Cox, 2012). As such, it is expected that the arrival of short-term rentals to residential zones has a more significant impact on the business configuration, fostering food and beverage establishment openings.

The rest of the paper is organized as follows. Section 2 provides a review of the

\footnotetext{
${ }^{2}$ Not related to our research question, the only few papers that analyzes other Airbnb externalities in the European contexts are Garcia-López et al. (2020) about the effect of Airbnb on rental prices in Barcelona, Almagro and Dominguez-Iino (2019) about the effect of Airbnb in changing neighborhood amenities in Amsterdam and Fontana (2021) for the discontent against tourists induced by the Airbnbinduced tourism flows in London.
} 
extant literature on the effect of short-term rentals of local urban economic activities. Section 3 and Section 4 describe the data and methodology, respectively. Section 5 presents and discusses our main findings. We draw our conclusions and discuss future research directions in Section 6.

\section{Related literature}

The rise of the sharing economy and, in particular, the crucial role played by homesharing platforms, has spurred a burgeoning literature about its impact on local economies ${ }^{3}$. Most of the literature has been devoted to analyzing short-term rentals' effects on the real estate sector, documenting the deleterious impacts of Airbnb on housing prices and rents (Garcia-López et al., 2020; Barron et al., 2021). The reallocation of housing units away from long-term rentals to short-term rentals spurred by $\mathrm{P} 2 \mathrm{P}$ accommodations has induced a rise in housing rental prices. Similarly, the positive impact on housing prices has been rationalized as an increase in the option value of owning a housing unit, thanks to the possibility of short-renting and the capitalization of higher rental prices. The disruption effect of home-sharing platforms goes beyond the housing sector, negatively affecting the performance of traditional accommodations (Zervas et al., 2017; Li and Srinivasan, 2019), but at the same time, contributing to a more diversified supply accommodation offer and lowering prices due to the hotels' capacity-constrained during periods of pick demand (Farronato and Fradkin, 2018; Schaefer and Tran, 2021).

Although most of the literature so far has stressed the negative consequences of Airbnb on the local economy, the advent of short-term rentals has also brought positive externalities, stimulating neighborhood and residential investment ( $\mathrm{Xu}$ and $\mathrm{Xu}, 2021$; Bekkerman et al., 2021). In particular, Alyakoob and Rahman (2019) and Basuroy et al. (2020) analyze whether Airbnb has positively affected local food and beverage services. Alyakoob and Rahman (2019) consider neighborhood or ZIP code data for New York City whereas Basuroy et al. (2020) use aggregated information at the ZIP code level for the state of Texas. Both papers rely on a Difference-in-Differences (DiD) strategy that exploits the different timing and intensity in the entrance of Airbnb across geographical areas. In this way, they can identify the effect of Airbnb, measured

\footnotetext{
${ }^{3}$ For a comprehensive list of the contributions on the Airbnb economic impact, see table A1 in the Appendix.
} 
through the number of reviews or the number of reviews per household respectively, on restaurant performance by comparing high and low Airbnb intensity zones, before and after Airbnb entry. Both studies find that Airbnb positively affects restaurant outcomes: a $1 \%$ increase in the number of reviews per household leads to a $1.7 \%$ increase in the restaurant employment in New York (Alyakoob and Rahman, 2019); a $1 \%$ increase in the number of Airbnb reviews is associated with a $0.011 \%$ increase in the restaurant revenue in the state of Texas (Basuroy et al., 2020).

Our study also relates to the urban consumption literature (Glaeser et al., 2001). Several papers have shown how densely populated areas benefited from a great variety and provision of food-related establishments (Mazzolari and Neumark, 2012; Couture, 2013; Schiff, 2015; Couture and Handbury, 2020). Among the main channels that explain this trend rest on the overrepresentation of young people and the heterogeneity of ethnic origins citizens in urban areas. Both the number of local consumption amenities and their quality have been proved to play a role (Kuang, 2017). Particularly relevant to our research question are those studies that show how spatial frictions explain city's consumption, commuting and prices patterns. Many contributions highlight the role of local consumption (Davis et al., 2019; Eizenberg et al., 2021; Miyauchi et al., 2021): consumers are much less likely to visit venues that are far from their residence. This is key in our study since we analyze the Airbnb-induced demand effect on local consumption amenities. Although most of the literature has analyzed the role of consumption amenities from the residents' lens, we instead focus on how tourists foster the performance and the creation of food-related establishments near their accommodations.

\section{Data}

Given the expected local effects of Airbnb-induced demand, it is advisable to use the most fine-grained level of analysis available. Therefore, our primary geographical units of analysis are Madrid's census tract. Census tracts are the smaller statistical unit in Spain. In particular, the city of Madrid is organized in districts, neighborhoods and census tracts, from the largest to the smallest administrative unit (see Figure I). As census tracts are built to represent a similar population (1000-2 500 people) at a narrowly defined geographical resolution, they are suitable to analyze local effects. 
Figure I: Administrative units in Madrid.
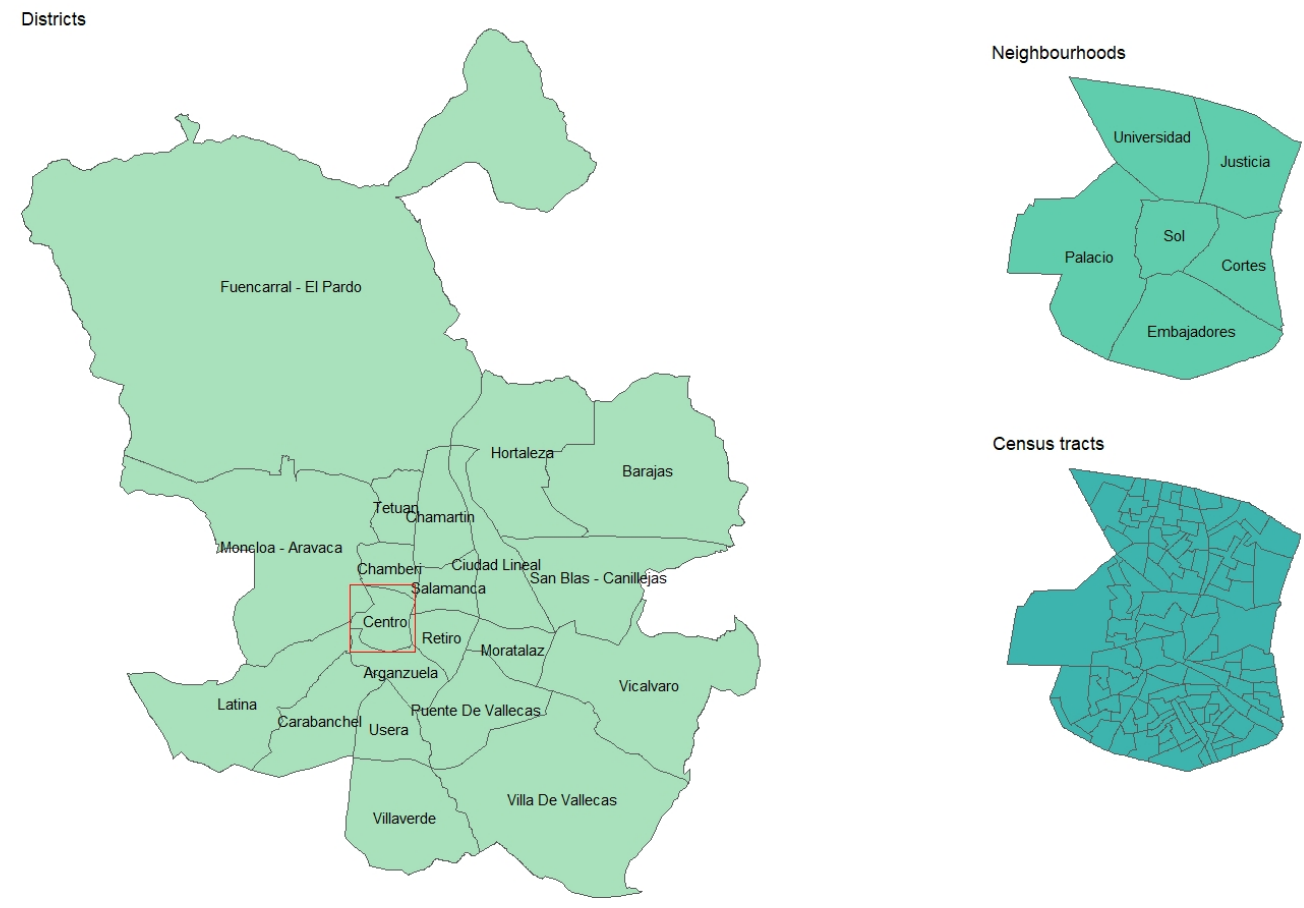

Census tracts

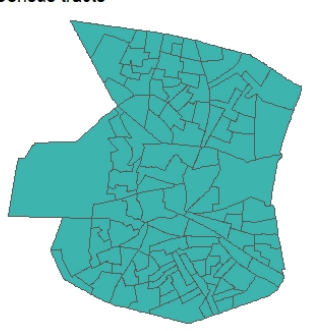

\subsection{Airbnb}

We build the Airbnb activity variable by collecting quarterly consumer-facing data from Inside Airbnb from March 2014 to October 20184. As stated on its website, Inside Airbnb is an "independent, non-commercial set of tools and data that allows you to explore how Airbnb is being used in cities around the world". It offers listing information at different points in time from different cities around the world. For our purposes, we are mainly interested in the information regarding the geographical coordinates of the listing, the size, and insights about the short-term rentals' activity in Madrid. We must come up with a way to define when a listing is active or not. To do so, we use the date of the first and the last reviews as a proxy for the beginning and end of the period that the listing has been active in the platform. On top of that, we consider the number of rooms in each accommodation unit as a proxy of its size. In this manner, we are cor-

\footnotetext{
${ }^{4}$ Our time frame stops at the end of 2018 due to the approval of a regulatory plan for short-term rentals (Plan Especial de Hospedaje) by the Madrid city council at the beginning of 2019. Under the new regulation, short-term rental activity was constrained to certain city areas. Although the impact of such regulation was modest (Urquiaga et al., 2019), we took a conservative decision not to include data from 2019 onward.
} 
rectly identifying the potential critical mass of food and beverage establishments users ${ }^{5}$.

\subsection{Local consumption amenities}

We obtained quarterly information from the Madrid City Council's census of business premises. The database created by Madrid Statistic Department (Servicio de Estadistica Municipal) covers the universe of all business establishments in the Madrid municipality. The data set compresses establishment-level data under a four-digit NACE-based classification, location, and status (opening, closing, or under some reform). In particular, we are interested in the food and beverage establishments (NACE I.56) which corresponds to the main expenditures made in-situ by tourists in Spain (INE, 2020). In particular, previous research have shown for the case of Madrid that tourist expenditure is mainly concentrated in restaurants (Aparicio et al., 2021). For this reason, our main dependent variable will be the total number of food and beverage establishments at the census tract level. ${ }^{6}$

We also have accessed yearly food and beverage establishments employment from the Madrid Statistic Department. However, because the employment data is confidential, we only have access at the neighborhood level from 2012 until 2018. Therefore as a second dependent variable, we consider the number of employees of the food and beverage service sector at the neighborhood level.

\subsection{Control variables}

We complement our data set with a set of variables to control for other factors related to either the establishments or employment in the food and beverage business that has been shown important in previous studies as the population, the proportion of foreign people and the number of rooms in the traditional accommodations (hotels and hostels) (Mazzolari and Neumark, 2012; Schiff, 2015). Demographic variables were obtained from inhabitants' register statistics (Padrón Municipal), whereas traditional

\footnotetext{
${ }^{5}$ Previous contributions have trusted in different metrics of the Airbnb activity such as the simple number of listings (Xu and Xu, 2021), the number of reviews (Garcia-López et al., 2020; Barron et al., 2021) or the proportion of listing over the number of dwellings (Franco and Santos, 2021). In our analysis we consider alternative measures of Airbnb activity as robustness checks.

${ }^{6}$ For a list of all activities related to food and beverage establishments, please refer to the table A2 in the Appendix.
} 
accommodations information from Madrid City Council's census of business premises. Last, we get tenancy type information for the Spanish Census 2011, such as the number of rented or empty houses or the number of dwellings.

\subsection{Descriptive statistics}

The Airbnb activity and the number of food and beverage establishments have ramped up in Madrid over the analyzed period. Meanwhile the total hotel room supply has barely changed (see Figure II).

Figure II: Number of food and beverage establishments, Airbnb and hotel rooms from the 2nd semester 2014 to 2nd semester 2018.

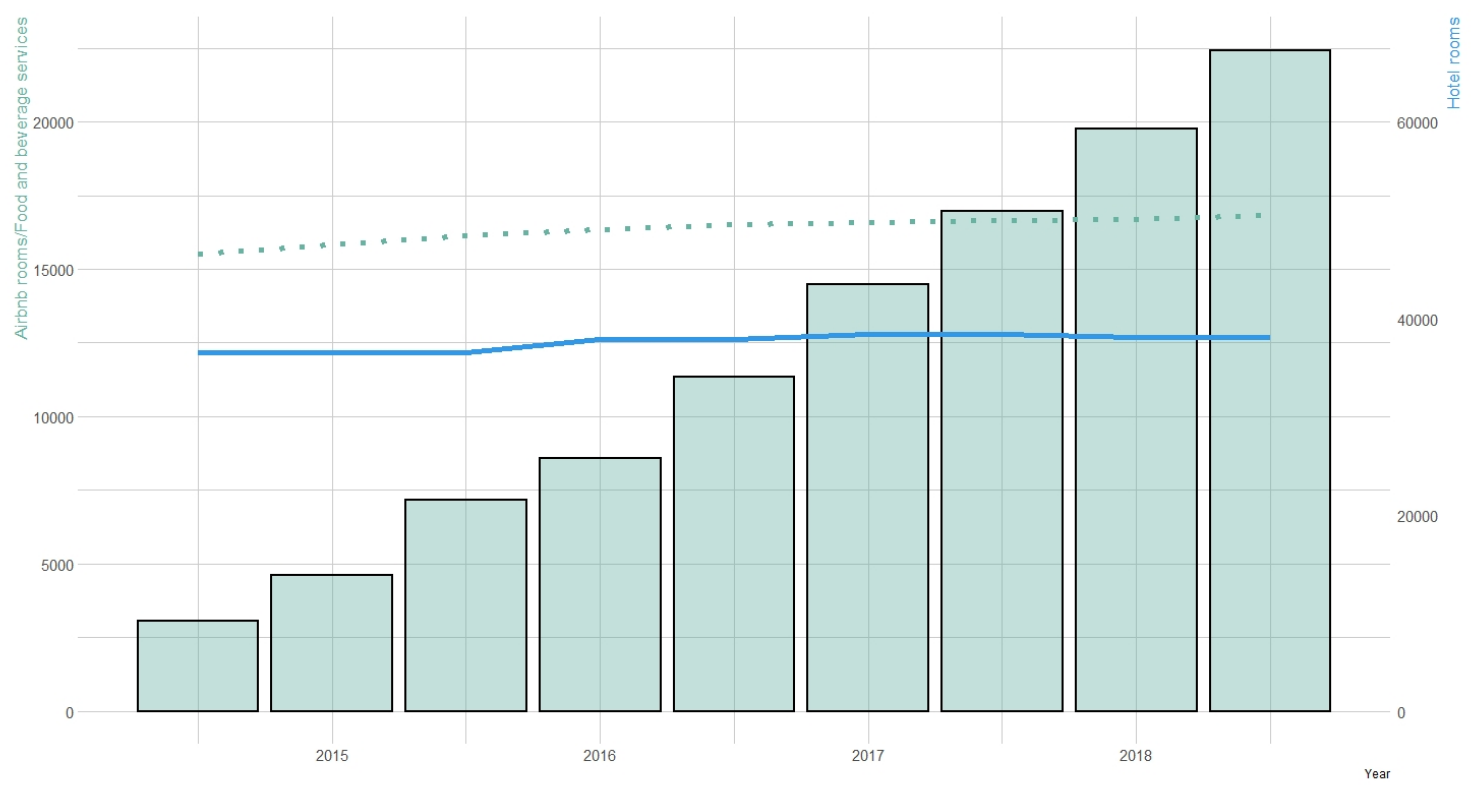

Notes: Left scale is for food and beverage establishments (dots) and Airbnb rooms (bars). Right scale is for hotel rooms (solid) evolution.

In Figure III, we can compare the geographical distribution of Airbnb rooms in April 2014 and April 2018. In 2014, short-term rental supply was almost exclusively in the Madrid city center's census tracts, with little or no presence elsewhere. Four years later, the situation has changed: even though most Airbnb rooms are still located downtown, the short-term rental supply has spread to more peripheral areas. As peer-to-peer accommodations are based on owners' dwellings, they can rapidly expand over the 
urban geography. In turn, Airbnb listings tend to localize near the touristic attractions that, in the case of Madrid, coincide with the city center and surroundings areas (Aparicio et al., 2021).

Figure III: Spatial distribution of Airbnb rooms in April 2014 (left) and April 2018 (right).

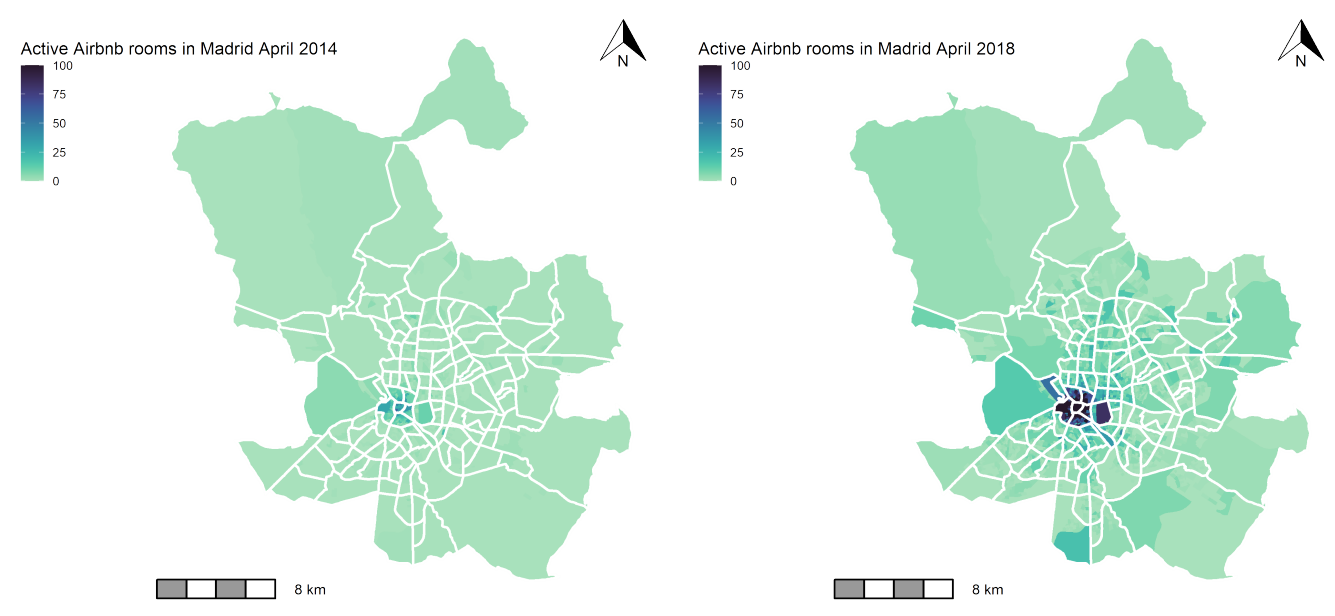

Notes: White lines delimit the administrative boundaries of neighborhoods, whereas the color intensity within neighborhoods reflects the number of Airbnb rooms in each census tracts.

\section{Methodology}

\subsection{Model specification}

The aim of this paper is to study the impact of Airbnb entry in Madrid on the local food and beverage sector. To answer our research question, we start with our baseline specification, that takes the following form:

$$
Y_{i, t}=\beta \operatorname{Airbnb}_{i, t}+\rho X_{i, t}+\delta_{t}+\gamma_{i}+\epsilon_{i, t}
$$

where $Y_{i, t}$ is the number of food and beverage establishments ${ }^{7}$ in a census tract $i$ in quarter $t, A_{i r b n b_{i, t}}$ is the number of rooms in Airbnb listings in each census tract, $X_{i, t}$

\footnotetext{
${ }^{7}$ Our baseline specification takes a level-level form due to a large number of census tracts with a low number of food and beverage establishments. Using a logarithmic transformation instead of levels, we would be giving more importance to small absolute changes than warrants. However, we also provide the results in the Appendix section in a log-log specification and a Poisson model. Our results do not depend on the specific functional of the model.
} 
are time-varying variables, $\delta_{t}$ are quarter specific fixed effects, and $\gamma_{i}$ are census tract fixed effects. Among the time-varying characteristics, we include the population, the proportion of foreign residents and the number of traditional accommodation rooms. With this set of variables, we aim at controlling for time-varying census-specific trends correlated with the number of food and beverage establishments and Airbnb listings, as a local process of urban revival or tourism trends other than short-term rentals. We include census tract fixed effect to account for time-invariant characteristics like the size area and quarter time fixed effect for cyclical or seasonal changes.

We are interested in $\beta$ of Eq. 1, which measures the average treatment effect of Airbnb on the number of food and beverage establishments. However, the number and type of Airbnb rooms are likely correlated with the disturbance term due to timevarying unobserved location characteristics (e.g., changing census tract amenities). Besides, we may have a problem of reverse causality as the number of food and beverage establishments might attract (agglomeration effect) or deter (inhibition effect) new Airbnb listings. Finally, we do not know precisely when they are active or not since we approximate the number of active Airbnb rooms with the number of listings with customer reviews. Therefore, our empirical setting calls for an instrumental variable (IV) strategy to deal with the endogeneity of our variable of interest.

Our IV strategy is based on a Bartik-like instrument, where we use as the initial shares, the number of rented houses in each census tract in 2011 (before Airbnb arrival to Madrid), and as the shift, the worldwide Airbnb Google searches ${ }^{8}$. It can be easily seen that, whereas the shares explain either the extensive and the intensive margin of the treatment, the shift describes timing. More formally,

$$
\text { Shift-Share } \text { Si,t }=z_{i, 2011} \times m_{t}
$$

where $z_{i}$ are the number of rented houses in census tract $i$ in 2011 , and $m_{t}$ are the normalized worldwide Airbnb Google searches. The relevance of our instrument rests on the fact that, as Horn and Merante (2017) have shown, the main mechanism through which Airbnb is expanding in the real estate sector is by decreasing the stock of longterm rentals whereas increasing the supply of short-term rentals. In fact, we can see

\footnotetext{
${ }^{8}$ This variable is measured at a quarterly level and is normalized to 100 for the month with the highest number of searches.
} 
that there is a positive and significant relationship between the number of rented houses and the posterior Airbnb activity (in Figure IV panel a). Moreover, we can also observe that the evolution for worldwide Airbnb Google Searches mimics the Airbnb growth (in Figure IV panel b).

Figure IV: Shift-share instrument relevance.

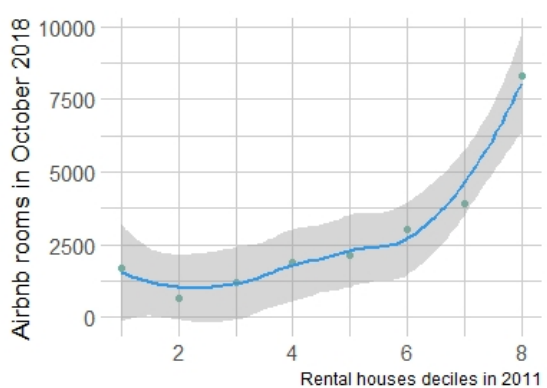

(a) Airbnb Madrid supply and rented houses.

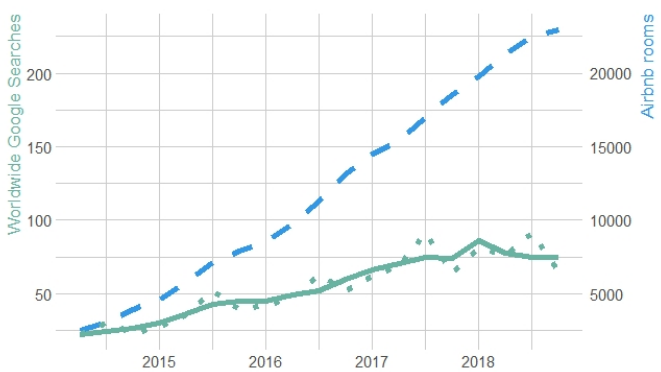

(b) Worldwide Airbnb Google searches and Airbnb Madrid supply.

Notes: Subplot (a) depicts how Airbnb supply is positively correlated with the number of rented houses represented by deciles. Subplot (b) shows the evolution of worldwide Airbnb Google searches (solid line: seasonally adjusted time series; dots are raw data) and the growth of Airbnb in Madrid (dashed line).

Differently from Garcia-López et al. (2020) and Barron et al. (2021), we rely on a supply share driver rather than a demand share for two reasons. First, the number of rented houses may predict the prospective Airbnb activity, not only in the city center but also in the rest of the urban area. Short-term rentals are based on owners' idle property, rather than construction. Therefore, between two census tracts located at the same distance to the city center, it is more likely that new Airbnb listings appear in the census tract with the higher number of rented houses as hosts may find it easier to switch from long-term rentals to short-term rentals rather than investing in new flats. Second, the number of tourist features used in Garcia-López et al. (2020) and Barron et al. (2021) may violate the exclusion restriction, as they are directly related to the distance to the city center where most of the tourist amenities are concentrated. Concerning our shift instrument, the number of worldwide Airbnb Google searches parallels the timing and expansion of Airbnb in Madrid, as Figure IV panel (b) shows. 
The basic idea behind the use of this shift is that potential hosts in Madrid are more likely to rent their property in the short-term market in response to growing interest in Airbnb as a global platform (Barron et al., 2021).

Concerning the exclusion restriction, it is highly unlikely that worldwide Airbnb Google searches are directly correlated with the increase in the aggregate attractiveness of Madrid. Airbnb is an global company with a presence in more than 100,000 cities in over 190 countries. Therefore, we can safely claim that the shift part of our Bartik-like instrument is exogenous to local conditions in Madrid. On the other hand, to satisfy the exclusion restriction, our share instrument $z_{i, 2011}$ must be only correlated with the changes in our dependent variable through the effect of Airbnb. In our setting, the main channel through which the stock of rented houses before Airbnb's arrival should affect the number of food and beverage establishments is through the switch from long-term rentals to short-term rentals driven by Airbnb. On the one hand, our exclusion restriction is backed up by the empirical evidence showing that consumption patterns regarding food and beverage services do not differ between homeowners and tenants (Reichenberger, 2012). On the other hand, as tourists (short-term rentals tenants) have different consumption patterns than residents (long-term rentals tenants), we should expect that Airbnb's arrival fosters local consumption amenities in the treated areas. Our instrument will be invalid if long-term residents' taste towards tourism-related activities changes over the study period. However, we think that this is quite unlikely in our relatively short panel setting.

A potential violation of our exclusion restriction may stem from the non-random location of the Airbnb listings, as most short-term rentals are in the city center. The main challenge that we are facing due to this non-random Airbnb listing location is to disentangle the impact of Airbnb on food and beverage establishments from other effects triggered by traditional accommodations or local visitors. For instance, the number of food and beverage establishments may be increasing due to the additional tourist flows coming from new or existing hotels in areas identified by our instrument as having high levels of rented houses prior to the arrival of Airbnb and, potentially, a large number of Airbnb rooms thereafter. This phenomenon takes special relevance for the case of Madrid, where tourists are mainly concentrated in the city center (GarcíaPalomares et al., 2015; Salas-Olmedo et al., 2018; Aparicio et al., 2021). That issue 
is partially solved by controlling for time-varying accommodation activities directly affecting tourist-related business like traditional accommodations rooms. Still, we can not rule out other phenomena like, for example, a taste change for locals towards eating out in the city center or a higher demand for the existing accommodations units.

Moreover, whenever the assumption about local tourist consumption does not hold, we will be overestimating the impact of Airbnb, as short-term rental guests whose listings are outside the city center are more likely to commute and consume downtown, where most of touristic amenities are located. For this reason, we decided to remove all census tracts located in the six neighborhoods that conform to the district "Centro" in Madrid $^{9}$. Our decision to drop observations in the city center is conservative since we expect that most Airbnb-induced demand affects those areas where most of the Airbnb activity is located (see Figure III). Despite that, we are still able to identify the effect of Airbnb on food and beverage establishments since Airbnb is spread around the city and may attract visitors to some areas that are outside of the touristic circuit, where we do not have the problem of other confounded tourist effects. Consequently, we create two samples: the whole sample that includes all Airbnbs rooms in the city of Madrid and the restricted sample that excludes all census tracts within the district "Centro" of Madrid.

As it can be seen in Table 1 our decision is grounded in the different characteristics of the two samples. As the Airbnb activity, also the traditional accommodation activity is mostly present in those census tracts located in the city center (see also Figure A1 and Figure A2 in the Appendix): nearly one-third of the overall Airbnb activity and the traditional accommodation industry is located in the city center ${ }^{10}$. The fast and unequal diffusion of $\mathrm{P} 2 \mathrm{P}$ accommodation across the urban geography, together with the modest increase of other types of accommodations, allow us to single out the impact of Airbnb on the food and beverage sector.

\footnotetext{
${ }^{9}$ The district "Centro" is conformed by the following neighborhoods: Sol, Palacio, Embajadores, Universidad, Cortes and Justicia.

${ }^{10}$ The rest of the hotel activity in Madrid is mainly concentrated in the areas near the airport or in the central business district (CBD). Both zones are far from the city center either in the extreme east (airport) or in the north (CBD).
} 
Table 1: Descriptive statistics, whole and restricted samples.

\begin{tabular}{|c|c|c|c|c|c|c|}
\hline \multirow{2}{*}{$\begin{array}{l}\text { Year } \\
\text { Variable }\end{array}$} & \multicolumn{3}{|c|}{2014} & \multicolumn{3}{|c|}{2018} \\
\hline & Sum & Mean & S.d. & Sum & Mean & S.d. \\
\hline \multicolumn{7}{|c|}{ Whole sample $(\mathrm{N}=41,800$, Census tracts $=2,200)$} \\
\hline Food and beverage establishments & 15761 & 7.164 & 8.438 & 16867 & 7.667 & 9.2 \\
\hline Airbnb listings & 2842 & 1.292 & 4.256 & 16128 & 7.331 & 15.424 \\
\hline Airbnb rooms & 3921 & 1.782 & 6.015 & 22949 & 10.431 & 22.912 \\
\hline Number of hotels & 298 & 0.135 & 0.652 & 307 & 0.14 & 0.675 \\
\hline Hotel rooms & 36497 & 16.59 & 83.744 & 38685 & 17.584 & 88.554 \\
\hline Foreign population (\%) & - & 0.156 & 0.102 & - & 0.177 & 0.117 \\
\hline Population & 2918109 & 1326.413 & 465.802 & 2944446 & 1338.385 & 454.234 \\
\hline \multicolumn{7}{|c|}{ Restricted sample $(\mathrm{N}=40,204$, Census tracts $=2,116)$} \\
\hline Food and beverage establishments & 13613 & 6.433 & 6.425 & 14533 & 6.868 & 7.143 \\
\hline Airbnb listings & 1473 & 0.696 & 2.274 & 10600 & 5.009 & 7.917 \\
\hline Airbnb rooms & 2037 & 0.963 & 3.19 & 14773 & 6.982 & 11.144 \\
\hline Number of hotels & 198 & 0.094 & 0.418 & 198 & 0.094 & 0.413 \\
\hline Hotel rooms & 27544 & 13.017 & 69.794 & 29064 & 13.735 & 74.697 \\
\hline Foreign population (\%) & - & 0.15 & 0.098 & - & 0.172 & 0.115 \\
\hline Population & 2816744 & 1331.164 & 470.37 & 2842928 & 1343.539 & 458.061 \\
\hline
\end{tabular}

\section{Results}

In this section, we summarize the main results of our analysis. First, we provide the estimates of the effect of Airbnb on the food and beverage sector, in general, and in selected activities of this sector, in particular. Then, we show how short-term rentals have affected employment in that sector, decomposing the overall Airbnb-induced employment effect between the intensive and the extensive margin. To check the validity of our findings, we perform a series of robustness checks to see whether our main tenets hold to the presence of potential confounders, alternative measures of our variable of interest, Airbnb activity, other sources of exogenous variation and the existence of pretrends, spatial spillovers and different geographical unit of analysis.

Table 2 presents the main results of our baseline OLS specification for the whole sample (columns 1-3) and the restricted sample (columns 4-6). Our baseline sample 
includes 2,200 census tracts for the whole sample and 2,116 for the restricted sample for 19 quarters, from April 2014 until October 2018. Our dependent variable is the number of food and beverage establishments. In columns 1 and 4, we regress the number of food and beverage establishments on the number of Airbnb rooms. Then, we augment this regression with time-varying additional controls in columns 2 and 5. Due to the potential existence of time-invariant census-specific characteristics related to the number of food and beverage establishments and the Airbnb activity or the existence of a common trend that affect equally all our geographical units, we add census tract and quarter fixed effects in columns 3 and 6.

Table 2: The Impact of Airbnb on the number of food and beverage establishments (OLS).

\begin{tabular}{|c|c|c|c|c|c|c|}
\hline \multirow{2}{*}{$\begin{array}{l}\text { Dependent Variable: } \\
\text { Model: }\end{array}$} & \multicolumn{6}{|c|}{ Food and beverage establishments } \\
\hline & Whole sample & Whole sample & Whole sample & Restricted sample & Restricted sample & Restricted sample \\
\hline \multicolumn{7}{|l|}{ Variables } \\
\hline \multirow[t]{2}{*}{ (Intercept) } & $5.679^{* * *}$ & $1.417^{* * *}$ & & $5.262^{* * *}$ & $1.013^{* * *}$ & \\
\hline & $(0.0398)$ & $(0.1157)$ & & $(0.0350)$ & $(0.1067)$ & \\
\hline \multirow[t]{2}{*}{ Airbnb rooms } & $0.3179^{* * *}$ & $0.2584^{* * *}$ & $0.0261^{* * *}$ & $0.4193^{* * *}$ & $0.3530^{* * *}$ & $0.0498^{* * *}$ \\
\hline & $(0.0071)$ & $(0.0063)$ & $(0.0018)$ & $(0.0098)$ & $(0.0100)$ & $(0.0039)$ \\
\hline \multirow[t]{2}{*}{ Population } & & $0.0021^{* * *}$ & $0.0034^{* * *}$ & & $0.0022^{* * *}$ & $0.0034^{* * *}$ \\
\hline & & $\left(7.43 \times 10^{-5}\right)$ & $(0.0002)$ & & $\left(6.78 \times 10^{-5}\right)$ & $(0.0002)$ \\
\hline \multirow[t]{2}{*}{ Foreign Population (\%) } & & $7.652^{* * *}$ & $-1.515^{* * *}$ & & $7.770^{* * *}$ & $-1.581^{* * *}$ \\
\hline & & $(0.3394)$ & $(0.3687)$ & & $(0.2930)$ & $(0.3723)$ \\
\hline \multirow[t]{2}{*}{ Hotel rooms } & & $0.0308^{* * *}$ & $0.0032^{* * *}$ & & $0.0251^{* * *}$ & $0.0029^{* * *}$ \\
\hline & & $(0.0014)$ & $(0.0009)$ & & $(0.0016)$ & $(0.0011)$ \\
\hline \multicolumn{7}{|l|}{ Fixed-effects } \\
\hline Quarters & No & No & Yes & No & No & Yes \\
\hline Census tract & No & No & Yes & No & No & Yes \\
\hline \multicolumn{7}{|l|}{ Fit statistics } \\
\hline Observations & 41,800 & 41,800 & 41,800 & 39,691 & 39,691 & 39,691 \\
\hline $\mathrm{R}^{2}$ & 0.32040 & 0.42717 & 0.98984 & 0.10787 & 0.22286 & 0.98291 \\
\hline
\end{tabular}

Notes: Statistical significance at the 1,5 and $10 \%$ levels is indicated by $* * * * *$ and $*$, respectively. Heteroskedasticity standard errors for columns 1-2 and 4-5 and cluster standard errors at the census tract level for columns 3 and 6 . Time trend and distance to the center interaction in columns 3 and 6 .

At first glance, the results do not crucially depend on the selected model: in all models we find a positive and significant effect of Airbnb activity on the number of food and beverage establishments. The inclusion of controls makes the coefficients for Airbnb activity somewhat reduced. However, they remain significant across all the specifications. Interestingly, the effect of Airbnb on the number of food and beverage establishments is lower in the whole sample than in the restricted sample. In this regard, it seems that Airbnb has a more significant impact on non-tourist areas as this 
P2P platform may be seen as a substitute for hotels Zervas et al. (2017). Therefore, the Airbnb-induced tourism effect is attenuated whenever other accommodations are around. Also, the opportunity cost of opening new establishments is lower in areas outside downtown due to a downward-sloping commercial rent gradient, although the COVID-19 disruption may attenuate this trend (Rosenthal et al., 2021).

It is worth noticing that our measure of Airbnb activity approximately accounts for the number of tourists, as we are weighting the number of listings by its respective number of rooms. Therefore, taking the most demanding specification (column 6), we can observe that the effect of one additional room is bigger than the inclusion of one resident, as we should expect since short-term residents have different consumption patterns than long-term residents ${ }^{11}$. We must be aware that this effect provides a lower bound of the overall impact since P2P accommodations are not fully booked during the whole year. In contrast, it is plausible to argue that residents remain at home most of the time.

Likewise, the number of traditional accommodation rooms contributes positively to the change in food and beverage establishments. However, the effect of traditional accommodations is much lower in magnitude than $\mathrm{P} 2 \mathrm{P}$ accommodations. At first sight, the greater impact of the P2P accommodations looks counterintuitive since most Airbnb listings provide kitchen facilities. However, a potential explanation for the smaller effect of traditional accommodation on the number of food and beverage establishments rests on the fact that hotels already provide food and beverage inside the facilities; therefore, there is less scope for positive externalities in nearby areas. Moreover, as described in the previous Section 4, the number of traditional accommodation rooms barely changed in Madrid in the period we consider.

Although we control for an extensive range of factors, we can not rule out unobserved time-varying characteristics related to Airbnb activity and the changes in the number of food and beverage establishments. Therefore, we use an instrumental variable strategy to overcome the potential problem of endogeneity in the Airbnb activity

\footnotetext{
${ }^{11}$ Another measure for the Airbnb-induced tourist activity is shown in a posterior analysis in Table 6, where, instead of using the number of short-term rentals rooms as the variable of interest, we use the number of guests. Again, we find that the effect of one additional Airbnb guest is seven times bigger than adding a new resident.
} 
variable. Furthermore, as in Garcia-López et al. (2020), we also include the interaction between a time trend and the distance to the center ${ }^{12}$ to allow for different trends according to the geographical location of each census tract. Table 3 shows the first and second-stage results for our most preferred specification (time-varying control variables plus quarter and census tract fixed effects). We can observe that our instrument - the interaction between the number of rented houses in 2011 and the worldwide Airbnb Google searches - predicts the Airbnb activity. In the second stage, we can see that the sign of the Airbnb effect remains positive and the magnitude has increased.

In economic terms, our estimates for the restricted sample imply that for each increase in ten Airbnb rooms, the number of food and beverage establishments increases on average in the unity in each census tract. Moreover, the IV coefficient (column 4 of table Table 3) is more than twice larger than the OLS (column 6 of table Table 2). The downward bias in the OLS estimates may be explained by omitted factors positively correlated with the presence of Airbnb in a census tract but negatively related to the change in the number of food and beverage establishments. Also, measurement errors might play a role in biasing our OLS estimates toward zero since we do not know with precision whether an Airbnb is active or not, but only an approximation. Lastly, the IV coefficients reflect the effect of converting the stock of rented houses into short-term rentals, whereas the OLS specification estimates only the effect of the number of short-term rentals. Consequently, in the presence of heterogeneity of the effect, IV-coefficients estimate the local average treatment effect (LATE) on compilers; that is, we estimate the effect in those census tracts identified by our instrument as having a high number of homes rented before Airbnb's arrival and potentially a large number of short-term rental rooms afterwards.

\footnotetext{
${ }^{12}$ We measure the distance to the center as the distance from Puertal del Sol (main square in Madrid city) to the centroid of each census tract.
} 
Table 3: The impact of Airbnb on the number of Food and BeVerage establishments (IV).

\begin{tabular}{|c|c|c|c|c|}
\hline \multirow{2}{*}{$\begin{array}{l}\text { Dependent Variable: } \\
\text { Model: }\end{array}$} & \multicolumn{4}{|c|}{ Food and beverage establishments } \\
\hline & $\begin{array}{c}\text { Whole sample } \\
\text { (First Stage) }\end{array}$ & $\begin{array}{l}\text { Whole sample } \\
\text { (Second Stage) }\end{array}$ & $\begin{array}{c}\text { Restricted sample } \\
\text { (First Stage) }\end{array}$ & $\begin{array}{c}\text { Restricted sample } \\
\text { (Second Stage) }\end{array}$ \\
\hline \multicolumn{5}{|l|}{ Variables } \\
\hline Airbnb rooms & & $\begin{array}{c}\mathbf{0 . 0 5 6 3}^{\text {*** }} \\
(0.0127)\end{array}$ & & $\begin{array}{c}\mathbf{0 . 1 2 1 7 ^ { * * * }} \\
(0.0379)\end{array}$ \\
\hline Shift-share & $\begin{array}{c}0.0009^{* * *} \\
\left(9.8 \times 10^{-5}\right)\end{array}$ & & $\begin{array}{c}0.0003^{* * *} \\
\left(2.95 \times 10^{-5}\right)\end{array}$ & \\
\hline Population & $\begin{array}{l}-0.0004 \\
(0.0006)\end{array}$ & $\begin{array}{c}0.0034^{* * *} \\
(0.0006)\end{array}$ & $\begin{array}{c}0.0007^{* * *} \\
(0.0002)\end{array}$ & $\begin{array}{c}0.0033^{* * *} \\
(0.0006)\end{array}$ \\
\hline Foreign Population (\%) & $\begin{array}{c}-17.84^{* * *} \\
(6.214)\end{array}$ & $\begin{array}{l}-0.8680 \\
(0.9789)\end{array}$ & $\begin{array}{c}-7.628^{* * *} \\
(1.942)\end{array}$ & $\begin{array}{l}-0.9879 \\
(1.018)\end{array}$ \\
\hline Hotel rooms & $\begin{array}{l}0.0381^{* * *} \\
(0.0131)\end{array}$ & $\begin{array}{c}0.0019 \\
(0.0017)\end{array}$ & $\begin{array}{l}0.0173^{* *} \\
(0.0073)\end{array}$ & $\begin{array}{c}0.0016 \\
(0.0021)\end{array}$ \\
\hline \multicolumn{5}{|l|}{ Fixed-effects } \\
\hline Quarters & Yes & Yes & Yes & Yes \\
\hline Census tract & Yes & Yes & Yes & Yes \\
\hline \multicolumn{5}{|l|}{ Fit statistics } \\
\hline Observations & 41,800 & 41,800 & 39,691 & 39,691 \\
\hline KP F-statistic & 89.1 & & 105.4 & \\
\hline
\end{tabular}

Notes: Statistical significance at the 1,5 and $10 \%$ levels is indicated by $* * *, * *$ and ${ }^{*}$, respectively. ShiftShare represents the interaction between the number of rented houses in 2011 and the worldwide Airbnb Google searches. Time trend and distance to the center interaction include in all specifications but not shown.

So far, we have analyzed the Airbnb-induced tourism demand effect on the number of food and beverage establishments. However, our data set allow us to see whether Airbnb also fosters the entry of some local consumption amenities in particular. Therefore, in Table A4 in the Appendix section we run our preferred specification of the IV model using as dependent variables: the number of restaurants, the number of bars, the number of coffees and the number of clubs. We find a larger effect on the first and third categories. This makes perfect sense since restaurants are the most touristoriented food and beverage establishments, whereas bars are also used regularly by locals. In line with our previous findings, the sums of each category approximately return our coefficient, 0.1217 food and beverage establishments per census tract per 
quarter, as expected since we are estimating a linear additive specification.

Along with the analysis, we have been focusing on the impact of Airbnb on the number of food and beverage establishments. However, the employment in that activity may have grown as well. Unfortunately, we do not have access to restaurant employment at the census tract level, but only at neighborhood level on a yearly basis. So, to test whether employment in the restaurant industry has been affected by the entry of Airbnb in Madrid, we replicate our IV specification using the neighborhoods as our geographical unit of analysis and years as our time frame. Table 4 summarizes the main findings. For the sake of comparison, we also reproduce the results for the number of food and beverage establishments with the same spatial and temporal breakdown.

Table 4: The Impact of Airbnb on the Food and Beverage Establishments employment AND FOOD AND BEVERAGE ESTABLISHMENTS AT THE NEIGHBORHOOD LEVEL (IV).

\begin{tabular}{lcccc}
\hline \hline Dependent Variable: & \multicolumn{2}{c}{ Food and beverage establishments } & Employment \\
\hline \hline Model: & Whole sample & Restricted sample & Whole sample & Restricted sample \\
\hline Variables & & & & \\
Airbnb rooms & $\mathbf{0 . 0 3 5 5 * * *}^{* * *}$ & $\mathbf{0 . 0 5 6 3}^{* * *}$ & $\mathbf{0 . 4 3 0 9}^{*}$ & $\mathbf{0 . 8 9 7 \mathbf { 2 } ^ { * * }}$ \\
& $(0.0051)$ & $(0.0161)$ & $(0.2272)$ & $(0.3941)$ \\
Population & $0.0045^{* * *}$ & $0.0043^{* * *}$ & $-0.0561^{*}$ & -0.0201 \\
& $(0.0009)$ & $(0.0010)$ & $(0.0322)$ & $(0.0123)$ \\
Foreign Population (\%) & -27.94 & -21.48 & $3,008.7$ & 698.6 \\
& $(34.52)$ & $(34.56)$ & $(2,206.1)$ & $(780.6)$ \\
Hotel rooms & 0.0026 & 0.0081 & 0.0296 & -0.1622 \\
& $(0.0049)$ & $(0.0051)$ & $(0.2830)$ & $(0.1543)$ \\
\hline Fixed-effects & & & & Yes \\
Neighborhood & Yes & Yes & Yes & Yes \\
Year & Yes & Yes & Yes & 600 \\
\hline Fit statistics & & & 640 & \\
Observations & 640 & 600 & $* * * *$ &
\end{tabular}

Notes: Statistical significance at the 1, 5 and $10 \%$ levels is indicated by ${ }^{* * *}, * *$ and ${ }^{*}$, respectively. Cluster standard errors at the census tract level. Time trend and distance to the center interaction include in all specifications but not shown.

As before, we notice that the effect of Airbnb on local consumption amenities is 
more prominent in the least touristic areas. Overall, the effect of Airbnb activity on employment is greater than in the number of food and beverage establishments, as the employment variable is jointly picking the effect of the extensive margin (positive variation in the number of restaurants) and in the intensive margin (positive variation in the employment of the existing restaurants). Due to the inaccessibility to individual employment data, we can not disentangle one effect from the other. However, we can obtain a back-of-envelope estimate under the assumption that new restaurants and existing restaurants vary the employment equally ${ }^{13}$. If this condition holds, the extensive margin would account for about two-thirds of the total variation in employment regardless of the sample used. In particular, for the whole sample, the intensive margin would explain $27,05 \%$ and the extensive margin $72,95 \%$ of the variation in the employment of restaurants ${ }^{14}$.

\subsection{Robustness checks}

\subsubsection{Falsification test: the impact of Airbnb on other local economic ac- tivities}

We are fully aware that, in our analysis, there might still be census-tract specific timevarying unobservables correlated with Airbnb and the number of food and beverage establishments. To test that our findings are only driven by Airbnb and not other factors, we exploit the fact that P2P accommodations should only affect tourist-related activities, in general, and local consumption amenities in particular. Therefore, we perform our analysis on those activities which may be related to a confounding phenomenon, like urban revival (Behrens et al., 2018) as professional, scientific, technical, financial and insurance activities ${ }^{15}$. The existence of this confounder correlated with the presence of Airbnb and the number of food and beverage establishments may invalidate our identification strategy as we will erroneously claim that Airbnb is behind the explosion in the number of food and beverage establishments. Conversely, if there is no unobserved time-varying trend, we should not find any effect of Airbnb on those economic activities as Airbnb mainly foster tourist-related activities.

\footnotetext{
${ }^{13}$ The proof of the approximation decomposition is provided in the Appendix section.

${ }^{14}$ For the restricted sample, the intensive margin explains $33,73 \%$ and the extensive margin $66,27 \%$, respectively

${ }^{15}$ For a list of all activities related with those sectors, please refer to the table A2 in the Appendix. This information was collected from the Madrid City Council's census.
} 
Table 5 presents the results for "Professional, scientific and technical" activities and "Finance and insurance" activities for the restricted sample. Knowing that census tracts in which those activities are present may be different from those with food and beverage establishments, we perform the falsification analysis on our initial census tracts sample, that is, those census tracts where there are food and beverage establishments and at least one of those non-tourist related activities. Clearly, results in Table 5 show no effect of Airbnb on non-tourist related activities.

Table 5: The Impact of Airbnb on the number of "Professional, scientific and techNiCAL" aCtivities And "Finance And insurance aCtivities" (IV).

\begin{tabular}{|c|c|c|c|c|}
\hline \multirow{2}{*}{$\begin{array}{l}\text { Dependent Variable: } \\
\text { Model: }\end{array}$} & \multicolumn{2}{|c|}{ Professional, scientific and technice } & \multicolumn{2}{|c|}{ Finance and insurance } \\
\hline & Whole sample & Restricted sample & Whole sample & Restricted sample \\
\hline \multicolumn{5}{|l|}{ Variables } \\
\hline \multirow[t]{2}{*}{ Airbnb rooms } & 0.0048 & 0.0094 & -0.0094 & -0.0332 \\
\hline & $(0.0042)$ & $(0.0142)$ & $(0.0082)$ & $(0.0286)$ \\
\hline \multirow[t]{2}{*}{ Population } & $0.0006^{* * *}$ & $0.0006^{* * *}$ & $0.0008^{* * *}$ & $0.0008^{* * *}$ \\
\hline & $(0.0001)$ & $(0.0001)$ & $(0.0002)$ & $(0.0002)$ \\
\hline \multirow[t]{2}{*}{ Foreign Population (\%) } & 0.2338 & 0.2476 & 0.1534 & 0.1588 \\
\hline & $(0.3813)$ & $(0.4239)$ & $(0.6618)$ & $(0.7542)$ \\
\hline \multirow[t]{2}{*}{ Hotel rooms } & 0.0003 & 0.0001 & 0.0022 & 0.0032 \\
\hline & $(0.0007)$ & $(0.0008)$ & $(0.0017)$ & $(0.0022)$ \\
\hline \multicolumn{5}{|l|}{ Fixed-effects } \\
\hline Quarters & Yes & Yes & Yes & Yes \\
\hline Census tract & Yes & Yes & Yes & Yes \\
\hline \multicolumn{5}{|l|}{ Fit statistics } \\
\hline Observations & 41,800 & 39,691 & 41,800 & 39,691 \\
\hline
\end{tabular}

Notes: Statistical significance at the 1, 5 and $10 \%$ levels is indicated by ${ }^{* * *}, * *$ and $*$, respectively. Cluster standard errors at the census tract level. Time trend and distance to the center interaction include in all specifications but not shown.

\subsubsection{Alternative measures of Airbnb activity}

The consumer-facing information retrieved from Inside Airbnb compresses a great variety of size-related variables like the number of rooms, the number of beds and the maximum number of guests for each listing. The number of Airbnb rooms may be not the right measure to identify the Airbnb activity as it may be capturing some housing 
characteristics of some areas of the city. As each variable conveys different information from the listing size, we decide to check whether our results are robust using different measures of Airbnb activity. Table 6 provides evidence from the most aggregate measure (listings) to the least aggregate (number of guests). As can be seen, the positive and significant effect remains across all specifications. 
Table 6: The impact of Airbnb on the number of Food And Beverage EstabLishments Using ALternative measures of Airbnb aCtivity (IV).

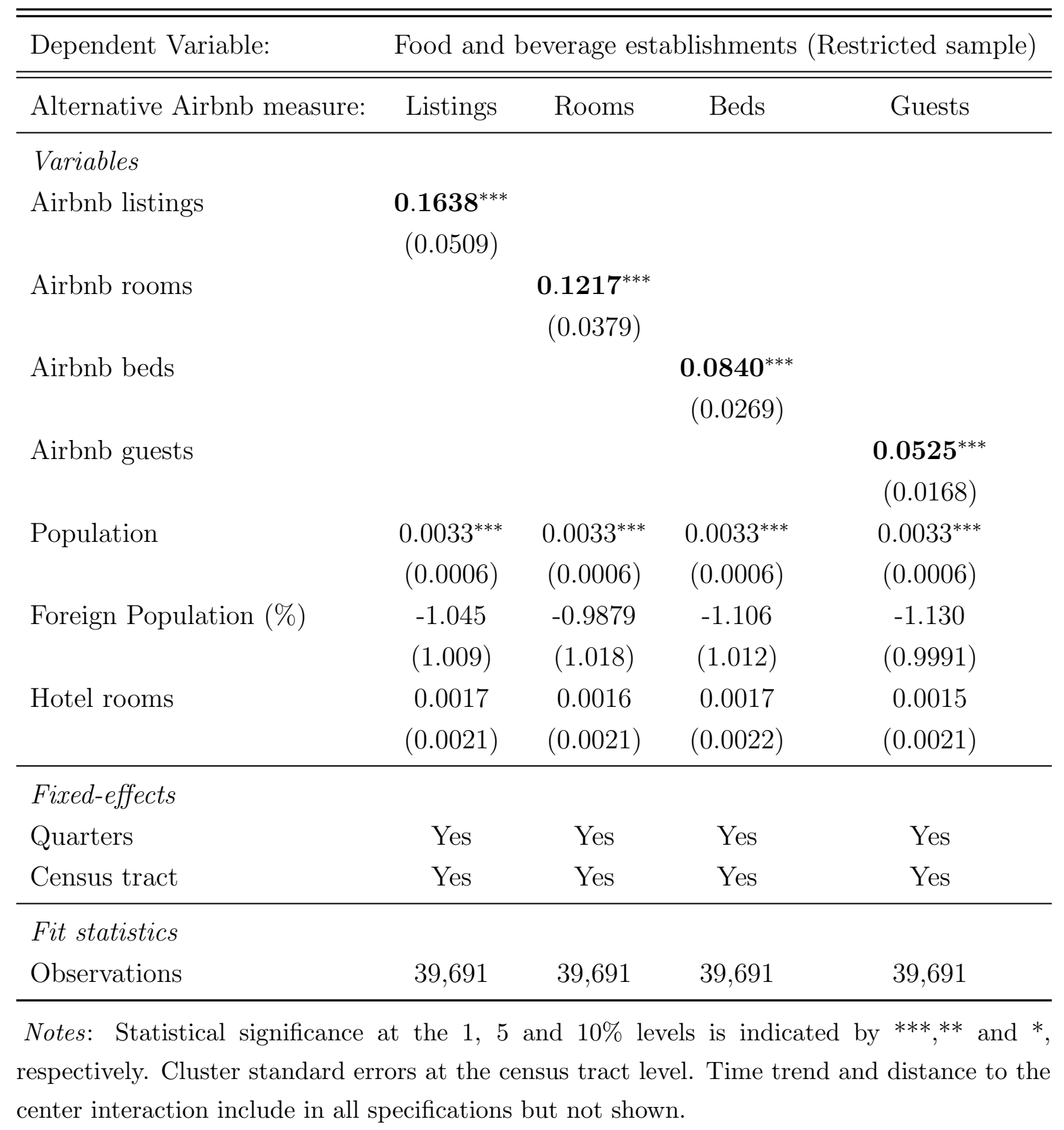




\subsection{IV validity}

\subsubsection{IV validity check}

We follow Barron et al. (2021) to check whether our instrumental variable strategy predicts the changes in the number of food and beverage establishments for those census tracts that never experienced any Airbnb activity. The idea of this exercise is to prove whether the instrument is valid and it is only correlated with the dependent variable through its effects on Airbnb. In fact, as shown in Table A5 in the Appendix section, we do not find any significant relation between our instrument and the change in the number of food and beverage establishments in those census tracts.

One potential issue in our research design strategy is the existence of previous trends in the change of the number of food and beverage establishments for census tracts where the number of housing rentals was high in 2011, and therefore, the number of Airbnb listings was high afterwards. Our main identification strategy rests on the assumption of parallel trends in the change of the number of consumption amenities across census tracts with more and those with less rented houses before Airbnb arrival. An increasing (decreasing) change in the number of food and beverage establishments previous to Airbnb arrival in Madrid will invalidate our analysis by violating the exclusion restriction assumption. Unfortunately, we do not have information of the number on food and beverage establishments at the census tract level before 2014 . However, we can use the employment level data for food and beverage establishments at the neighborhood level from 2012 onward to check for parallel trends.

Therefore, following Goldsmith-Pinkham et al. (2020), we run the following event study

$$
Y_{i, t}=\sum_{t \neq 2014} \lambda_{t} \times \delta \text { Airbnb high activity }+\rho X_{i, t}+\delta_{t}+\gamma_{i}+\epsilon_{i, t}
$$

where we interact Airbnb high activity, a dummy variable for identifying those neighborhoods with Airbnb activity is high ${ }^{16}$, with year dummy variables $\lambda_{t}$, using 2014 year as the base year. We choose 2014 as our base year as, from this year,

\footnotetext{
${ }^{16}$ The top decile neighborhoods in terms of Airbnb activity are Sol, Palacio, Embajadores, Universidad, Cortes, Justicia, Palos de Moguer, Trafalgar, Goya, Arguelles, Guindalera, Puerta del Angel and Arapiles.
} 
the Airbnb activity in Madrid has become more significant. As our main results are driven mainly by those areas where the Airbnb activity is high, the main idea of this test is to check whether those areas were also experiencing a different trend in the evolution for the outcome variable. As can be seen in Figure V, the coefficients before Airbnb's entry are not different from zero. This result reassures that it was Airbnb behind the increase in the employment of the food and beverage sector. Therefore, we can conclude that there is no evidence suggesting a violation of the parallel trends assumption and Airbnb did not enter in neighborhoods after observing an expansion in food and beverage consumption amenities.

\section{Effect on Food and Beverage employment}

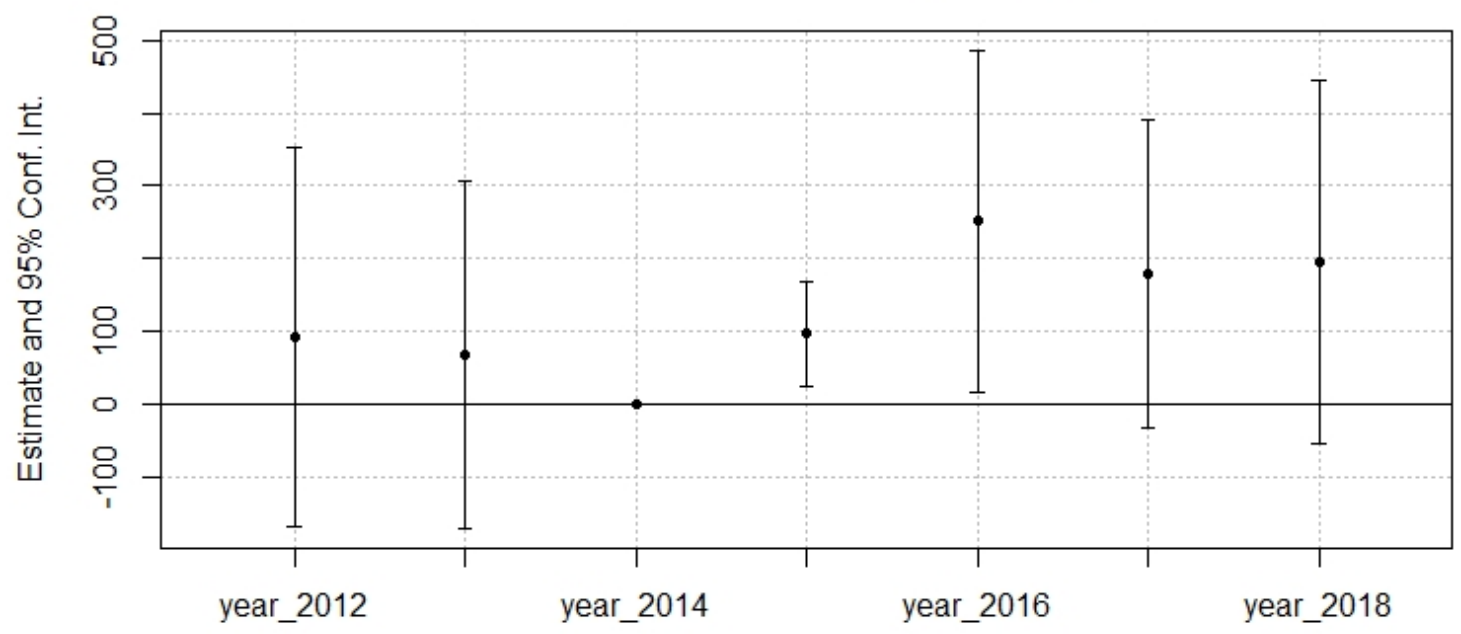

Figure V: Event study plots for the top decile Airbnb Neighborhoods.

\subsubsection{Alternative instruments}

The number of rental houses in 2011 interacted with the worldwide Airbnb Google searches has been used as our main Bartik-like instrument. So far, we have shown that our instrument does not predict the changes in the number of food and beverage establishments in those areas that ever had any Airbnb activity. Also, those areas that have a higher presence of Airbnb activity do not have any positive or negative pre-trend in the evolution of the employment for food and beverage establishments. 
To show that our main results hold no matter the source of exogenous variation exploited in our identification strategy, we select a series of supply share drivers instruments related to the number of food and beverage establishments only through their effect on the posterior evolution of Airbnb.

Table 7: The impact of Airbnb on the number food and BeVerage establishments using alternative instruMENTAL VARIABLES (IVS).

\begin{tabular}{|c|c|c|c|c|}
\hline \multirow{2}{*}{$\begin{array}{l}\text { Dependent variable: } \\
\text { Alternative Share Instruments: }\end{array}$} & \multicolumn{4}{|c|}{ Food and beverage establishments (Restricted sample) } \\
\hline & Total dwellings & Empty houses & Share of rented houses & Share of rented + empty houses \\
\hline \multicolumn{5}{|l|}{ Variables } \\
\hline \multirow[t]{2}{*}{ Airbnb rooms } & $0.0955^{* *}$ & 0.0709 & $0.1427^{* * *}$ & $0.1068^{* * *}$ \\
\hline & $(0.0421)$ & $(0.0696)$ & $(0.0385)$ & $(0.0411)$ \\
\hline \multirow[t]{2}{*}{ Population } & $0.0033^{* * *}$ & $0.0034^{* * *}$ & $0.0033^{* * *}$ & $0.0033^{* * *}$ \\
\hline & $(0.0006)$ & $(0.0006)$ & $(0.0006)$ & $(0.0006)$ \\
\hline \multirow[t]{2}{*}{ Foreign Population (\%) } & -2.269 & -2.542 & -1.744 & -2.144 \\
\hline & $(1.646)$ & $(1.849)$ & $(1.542)$ & $(1.579)$ \\
\hline \multirow[t]{2}{*}{ Hotel rooms } & 0.0020 & 0.0025 & 0.0012 & 0.0018 \\
\hline & $(0.0020)$ & $(0.0019)$ & $(0.0023)$ & $(0.0022)$ \\
\hline \multicolumn{5}{|l|}{ Fixed-effects } \\
\hline Quarters & Yes & Yes & Yes & Yes \\
\hline Census tract & Yes & Yes & Yes & Yes \\
\hline \multicolumn{5}{|l|}{ Fit statistics } \\
\hline Observations & 39,691 & 39,691 & 39,691 & 39,691 \\
\hline KP F-statistic & 103.9 & 26.27 & 75.5 & 97.1 \\
\hline
\end{tabular}

Notes: Statistical significance at the 1, 5 and $10 \%$ levels is indicated by ${ }^{* * *},{ }^{* *}$ and $*$, respectively. Cluster standard errors at the census tract level. Time trend and distance to the center interaction include in all specifications but not shown.

Table 7 shows that our main tenets hold with either an absolute measure as the total number of houses or a relative measure such as the proportion of rented houses or the proportion of rented and empty houses. In contrast, the number of empty houses does not predict the posterior Airbnb distribution. However, our share instrument lost relevance in most cases, as it can be seen by the lower values of the Kleibergen-Paap Wald F-test.

\subsection{Spatial analysis}

\subsubsection{Spillover effects}

So far, we were assuming that the Airbnb-induced tourism demand effect is constrained to the census tract where the Airbnb listing is located. This is a strong assumption considering the small size of our geographical unit of analysis. Although using census tracts allow us to capture better the effect of Airbnb on the number of food and 
beverage establishments, its reduced dimension makes them more salient to spillover problems from other $\mathrm{P} 2 \mathrm{P}$ accommodations in the surroundings census tracts than bigger administrative units like neighborhoods or ZIP codes. Not taking into account the presence of spillovers makes us overestimate, but also maybe underestimate the effect of Airbnb on the number of food and beverage establishments. On the one hand, the critical mass of potential customers increases with the Airbnb tourists of each census tract and the Airbnb guests of the neighbors census tracts. On the other hand, Airbnb may be shifting demand away from census tracts without short-term rentals due to the creation of food and beverage clusters, leading to an increase in the number of food and beverage establishments on the census tracts with a strong Airbnb presence and a decrease in the surrounding neighborhoods.

To account for the potential spillover effects in the census tracks due to the Airbnb, we use a spatial lag of X model (SLX) where we include the spatial lag of our variable of interest: the weighted number of Airbnb rooms in census tracts neighbors. The main reason of using a SLX model over other spatial econometric methods rests on the expected local effects; Airbnb guests are more willing to consume only in nearby census tracts. Therefore, we expect that Airbnb-induced tourism demand only affects nearby areas. One of the advantages of the SLX model is that it can be easily used with other standard econometric techniques (Halleck Vega and Elhorst, 2015). Therefore, we instrument the spatial lag of Airbnb rooms with the interaction between the worldwide Airbnb Google searches and the spatial lag of the number of rented houses in 2011.

Table 8 shows the results of our baseline specification where we have augmented it, including the Airbnb activity's spatial lag and, as its instrument, the spatial lag of our shift-share variable. Regardless of the spatial weight matrix use, we do not find evidence of the presence of spatial spillovers. Therefore, the SLX analysis suggests that our model is run at the appropriate level and allows us to capture the full effect of Airbnb on local consumption amenities. 
Table 8: The Impact of Airbnb on the number of FOOD AND Beverage ESTABLISHMENTS CONTROLLING FOR SPILLOVER EFFECTS (IV).

\begin{tabular}{|c|c|c|c|c|}
\hline \multirow{2}{*}{$\begin{array}{l}\text { Dependent variable: } \\
\text { Spatial matrix: }\end{array}$} & \multicolumn{4}{|c|}{ Food and beverage establishments (Whole sample) } \\
\hline & Cut-off distance & Inverse distance & Rook & Queen \\
\hline \multicolumn{5}{|l|}{ Variables } \\
\hline \multirow[t]{2}{*}{ Airbnb rooms } & $0.0974^{* * *}$ & $0.0860^{*}$ & $0.0886^{*}$ & $0.0867^{*}$ \\
\hline & $(0.0362)$ & $(0.0457)$ & $(0.0495)$ & $(0.0450)$ \\
\hline \multirow[t]{2}{*}{ Airbnb rooms neighbors } & -0.0540 & -0.0372 & -0.0394 & -0.0379 \\
\hline & $(0.0343)$ & $(0.0446)$ & $(0.0480)$ & $(0.0435)$ \\
\hline \multirow[t]{2}{*}{ Population } & $0.0033^{* * *}$ & $0.0034^{* * *}$ & $0.0034^{* * *}$ & $0.0034^{* * *}$ \\
\hline & $(0.0006)$ & $(0.0006)$ & $(0.0006)$ & $(0.0006)$ \\
\hline \multirow[t]{2}{*}{ Foreign Population (\%) } & -0.8902 & -1.030 & -1.056 & -1.049 \\
\hline & $(0.9894)$ & $(0.9483)$ & $(0.9450)$ & $(0.9468)$ \\
\hline \multirow[t]{2}{*}{ Hotel rooms } & 0.0014 & 0.0017 & 0.0016 & 0.0017 \\
\hline & $(0.0017)$ & $(0.0017)$ & $(0.0017)$ & $(0.0017)$ \\
\hline \multicolumn{5}{|l|}{ Fixed-effects } \\
\hline Quarters & Yes & Yes & Yes & Yes \\
\hline Census tract & Yes & Yes & Yes & Yes \\
\hline \multicolumn{5}{|l|}{ Fit statistics } \\
\hline Observations & 41,800 & 41,800 & 41,800 & 41,800 \\
\hline \multicolumn{5}{|c|}{$\begin{array}{l}\text { Notes: Statistical significance at the } 1,5 \text { and } 10 \% \text { levels is indicated by } * * *, * * \text { and } * \\
\text { respectively. Cluster standard errors at the census tract level. Cut-off distance set at } 300 \mathrm{~m} \\
\text { Rook criterion restrict the potential neighbors to those which share common sides of the } \\
\text { polygons. Queen criterion is built upon Rook criterion but also including common vertices } \\
\text { Time trend and distance to the center interaction include in all specifications but not shown }\end{array}$} \\
\hline
\end{tabular}

\subsubsection{Modifiable areal unit problem (MAUP)}

We further test whether our main tenets hold whenever we use the same regression specification, but changing our geographical unit of analysis. Instead of census tracts, 
we aggregate our data to neighborhood level and transports zones $^{17}$. The goal of this exercise is to address the ubiquitous statistical problem in spatial analysis framed as the Modifiable Areal Unit Problem (MAUP). Table 9 show that even though we find a positive and significant effect of Airbnb activity on the number of food and beverage establishments, this effect is higher in magnitude whenever we use our smaller geographical unit of analysis, the census tracts. The reduced size of that administrative unit of analysis allows us better to identify the tourism-induced effect of Airbnb as they are less heterogeneous effects than within neighborhoods or transport zones, which may explain the smaller magnitude of the coefficient.

Table 9: The Impact of Airbnb on the number of Food And BeVerage ESTABlishments (IV).

\begin{tabular}{|c|c|c|c|c|}
\hline \multirow{2}{*}{$\begin{array}{l}\text { Dependent Variable: } \\
\text { Model: }\end{array}$} & \multicolumn{4}{|c|}{ Food and beverage establishments } \\
\hline & $\begin{array}{l}\text { Whole sample } \\
\text { (Neighborhood) }\end{array}$ & $\begin{array}{c}\text { Restricted sample } \\
\text { (Neighborhood) }\end{array}$ & $\begin{array}{c}\text { Whole sample } \\
\text { (Transport zones) }\end{array}$ & $\begin{array}{l}\text { Restricted sample } \\
\text { (Transport zones) }\end{array}$ \\
\hline \multicolumn{5}{|l|}{ Variables } \\
\hline Airbnb rooms & $\begin{array}{c}0.0386^{* * *} \\
(0.0075)\end{array}$ & $\begin{array}{c}0.0718^{* * *} \\
(0.0249)\end{array}$ & $\begin{array}{c}0.0555^{* * *} \\
(0.0090)\end{array}$ & $\begin{array}{c}0.0952^{* * *} \\
(0.0147)\end{array}$ \\
\hline Population & $\begin{array}{c}0.0049^{* * *} \\
(0.0010)\end{array}$ & $\begin{array}{c}0.0047^{* * *} \\
(0.0011)\end{array}$ & $\begin{array}{c}0.0037^{* * *} \\
(0.0005)\end{array}$ & $\begin{array}{c}0.0034^{* * *} \\
(0.0005)\end{array}$ \\
\hline Foreign population (\%) & $\begin{array}{l}-27.68 \\
(36.17)\end{array}$ & $\begin{array}{l}-16.01 \\
(38.00)\end{array}$ & $\begin{array}{l}0.9345 \\
(5.929)\end{array}$ & $\begin{array}{l}0.7268 \\
(5.808)\end{array}$ \\
\hline Hotel rooms & $\begin{array}{c}0.0008 \\
(0.0043)\end{array}$ & $\begin{array}{c}0.0035 \\
(0.0049)\end{array}$ & $\begin{array}{l}-0.0013 \\
(0.0034)\end{array}$ & $\begin{array}{c}0.0005 \\
(0.0032)\end{array}$ \\
\hline Fixed-effects & & & & \\
\hline $\begin{array}{l}\text { Quarters } \\
\text { Neighborhood }\end{array}$ & $\begin{array}{l}\text { Yes } \\
\text { Yes }\end{array}$ & $\begin{array}{l}\text { Yes } \\
\text { Yes }\end{array}$ & Yes & Yes \\
\hline Transport zones & & & Yes & Yes \\
\hline $\begin{array}{l}\text { Fit statistics } \\
\text { Observations }\end{array}$ & 2,432 & 2,318 & 9,025 & 8,531 \\
\hline
\end{tabular}

Notes: Statistical significance at the 1, 5 and $10 \%$ levels is indicated by $* * * * *$ and $*$, respectively. Cluster standard errors at the census tract level.Time trend and distance to the center interaction include in all specifications but not shown.

\footnotetext{
${ }^{17}$ Transport zones (ZTs) constitute one of the basic spatial unit for analysis and aggregation of information in Madrid. They are defined by Madrid Regional Transport Consortium to collect information for doing surveys regarding the Madrid inhabitants mobility patterns. Its size approximates a scale of territorial division between the neighborhood and the census tract.
} 


\section{Conclusions}

This paper examines the impact of the most popular $\mathrm{P} 2 \mathrm{P}$ accommodation platform, Airbnb, on local consumption amenities. Using a fine-grained census of local store data set and exploiting the exogenous variation created by the rapid and unequal entry of the short-term rentals across Madrid geography, we find positive and significant effects in the number but also the employment of food and beverage establishments. Interestingly, the effect of Airbnb on local consumption amenities is greater in less touristic areas, reinforcing the idea that peer-to-peer accommodations help to redistribute tourism consumption across the city. We show that there are heterogeneous effects across the different activities within the local consumption amenities and that incumbents also benefit by the short-term rental disruption. Our results are very stable across different specifications: they are not driven by either the way of measure the Airbnb activity, the presence of unobserved time-varying trends related to gentrification or the existence of pre-trends. Moreover, we adopt a multi-scale specification (census tracts, transport zones and neighborhoods) to evaluate the multiplicity of spatial aspects within a single event. Lastly, we do not find evidence of the existence of geographical spillovers, and our main tenets hold regardless of the different scale of analysis.

With this paper, we contribute to the debate about the effects of the platform economy on urban areas. Even though most of the previous studies have focused on the negative consequences that P2P accommodations bring to the cities in terms of higher rental and housing prices, we show that it also contribute positively to the local economy by bringing economic activity to non-touristic areas. Hence, this study stresses the importance of taking into account the uneven effect of short-term rentals over urban geography. Considering the city as an homogeneous area entails the risk of masking heterogeneous effects, which may conduit to wrong public policies. Therefore, our study yields notable policy implications regarding Airbnb regulation by providing some reasons to allow short-term rentals outside the city centers due to the potentially higher positive economic spillovers. In fact, current legislation is following that direction in cities like Madrid or Barcelona (Urquiaga et al., 2019). On top of that, the redistribution of tourist inflows within the city is key to the survival of the sector because its deleterious effects on residents in central areas may fuel reactions against tourists, which could jeopardize the entire sector (Allen et al., 2020). 
In addition, we provide evidence that both margins (intensive and extensive) explains the employment increase in local consumption amenities. The intensive margin show that the positive effects also occur in existing food and beverage establishments. In this way, the increase in Airbnb-induced demand implies the possibility of taking advantage of economies of scale, and therefore, the increase in the efficiency and profitability of this activity usually identified as low productivity. The effect in the extensive margin show that the arrival of short-term rentals may help to improve the dynamism of the food and beverage services due to low entry costs. As such, tourism benefits are not only more evenly distributed across the city but also across the firms demography due to the high presence of small and medium-sized companies in the food and beverage sector.

Nevertheless, further research is needed. Although we have focused on this paper on the effect of short-term rentals on local consumption amenities, other economic activities may also be impacted by the arrival of $\mathrm{P} 2 \mathrm{P}$ accommodations. In this regard, a more holistic approach to how $\mathrm{P} 2 \mathrm{P}$ accommodations reshape cities is needed, considering the overall effect of short-term rentals across the geography of all economic activities. Since the IV approach we introduce in this paper is very general and can be applied to different cities, another possible future development is to extend our analysis to different urban areas. All things considered, the greater and undetermined externalities of $\mathrm{P} 2 \mathrm{P}$ accommodations deserve more consideration to understand its potential impact on urban areas. 


\section{References}

Allen, T., Fuchs, S., Ganapati, S., Graziano, A., Madera, R., and Montoriol-Garriga, J. (2020). Is tourism good for locals? evidence from barcelona. Dartmouth College, mimeograph.

Almagro, M. and Dominguez-Iino, T. (2019). Location sorting and endogenous amenities: Evidence from amsterdam. Technical report, Working Paper.

Alyakoob, M. and Rahman, M. S. (2019). Shared prosperity (or lack thereof) in the sharing economy. Available at SSRN 3180278.

Aparicio, D., Hernández Martín-Caro, M. S., García-Palomares, J. C., and Gutiérrez, J. (2021). Exploring the spatial patterns of visitor expenditure in cities using bank card transactions data. Current Issues in Tourism, pages 1-19.

Barron, K., Kung, E., and Proserpio, D. (2021). The effect of home-sharing on house prices and rents: Evidence from airbnb. Marketing Science, 40(1):23-47.

Basuroy, S., Kim, Y., and Proserpio, D. (2020). Estimating the impact of airbnb on the local economy: Evidence from the restaurant industry. Available at SSRN 3516983.

Behrens, K., Boualam, B., Martin, J., and Mayneris, F. (2018). Gentrification and pioneer businesses. CEPR Discussion Paper No. DP13296.

Bekkerman, R., Cohen, M. C., Kung, E., Maiden, J., and Proserpio, D. (2021). The effect of short-term rentals on residential investment. Available at SSRN.

Bibler, A., Teltser, K., and Tremblay, M. J. (2021). Is sharing really caring? the effect of airbnb on the affordability of housing. The Effect of Airbnb on the Affordability of Housing (May 15, 2021).

Calder-Wang, S. (2019). The distributional impact of the sharing economy on the housing market.

Chen, W., Wei, Z., and Xie, K. (2020). The battle for homes: How does home sharing disrupt local residential markets? Available at SSRN 3257521.

Couture, V. (2013). Valuing the consumption benefits of urban density. University of California, Berkeley. Processed. 
Couture, V. and Handbury, J. (2020). Urban revival in america. Journal of Urban Economics, 119:103267.

Davis, D. R., Dingel, J. I., Monras, J., and Morales, E. (2019). How segregated is urban consumption? Journal of Political Economy, 127(4):1684-1738.

Duso, T., Michelsen, C., Schaefer, M., and Tran, K. D. (2021). Airbnb and rental markets: Evidence from berlin.

Eizenberg, A., Lach, S., and Oren-Yiftach, M. (2021). Retail prices in a city. American Economic Journal: Economic Policy, 13(2):175-206.

Farronato, C. and Fradkin, A. (2018). The welfare effects of peer entry in the accommodation market: The case of airbnb. Technical report, National Bureau of Economic Research.

Ferreri, M. and Sanyal, R. (2018). Platform economies and urban planning: Airbnb and regulated deregulation in london. Urban Studies, 55(15):3353-3368.

Filippas, A. and Horton, J. J. (2020). The tragedy of your upstairs neighbors: The externalities of home-sharing platforms. Technical report, Working Paper.

Fontana, N. (2021). Blacklash against airbnb: Evidence from london. In Job Market Paper.

Franco, S. F. and Santos, C. D. (2021). The impact of airbnb on residential property values and rents: Evidence from portugal. Regional Science and Urban Economics, 88:103667.

Garcia, B., Miller, K., and Morehouse, J. M. (2020). In search of peace and quiet: The heterogeneous impacts of short-term rentals on housing prices.

Garcia-López, M.-À., Jofre-Monseny, J., Martínez-Mazza, R., and Segú, M. (2020). Do short-term rental platforms affect housing markets? evidence from airbnb in barcelona. Journal of Urban Economics, 119:103278.

García-Palomares, J. C., Gutiérrez, J., and Mínguez, C. (2015). Identification of tourist hot spots based on social networks: A comparative analysis of european metropolises using photo-sharing services and gis. Applied Geography, 63:408-417. 
Glaeser, E. L., Kolko, J., and Saiz, A. (2001). Consumer city. Journal of economic geography, 1(1):27-50.

Goldsmith-Pinkham, P., Sorkin, I., and Swift, H. (2020). Bartik instruments: What, when, why, and how. American Economic Review, 110(8):2586-2624.

Gordon, P. and Cox, W. (2012). Cities in western europe and the united states: do policy differences matter? The Annals of Regional Science, 48(2):565-594.

Halleck Vega, S. and Elhorst, J. P. (2015). The slx model. Journal of Regional Science, $55(3): 339-363$.

Hill, R. J., Pfeifer, N., Steurer, M., et al. (2020). The airbnb rent-premium and the crowding-out of long-term rentals. Technical report, University of Graz, Department of Economics.

Horn, K. and Merante, M. (2017). Is home sharing driving up rents? evidence from airbnb in boston. Journal of Housing Economics, 38:14-24.

INE (2020). Tourist Expenditure Survey (Egatur). Retrieved December 10, 2020 from: https://www.ine.es/dyngs/INEbase/es/operacion.htm?c=Estadistica_ C\&cid=1254736177002\&menu=ultiDatos\&idp=1254735576863.

Koster, H. R., van Ommeren, J., and Volkhausen, N. (2021). Short-term rentals and the housing market: Quasi-experimental evidence from airbnb in los angeles. Journal of Urban Economics, 124:103356.

Kuang, C. (2017). Does quality matter in local consumption amenities? an empirical investigation with yelp. Journal of Urban Economics, 100:1-18.

Li, H. and Srinivasan, K. (2019). Competitive dynamics in the sharing economy: An analysis in the context of airbnb and hotels. Marketing Science, 38(3):365-391.

Mazzolari, F. and Neumark, D. (2012). Immigration and product diversity. Journal of Population Economics, 25(3):1107-1137.

Miyauchi, Y., Nakajima, K., and Redding, S. J. (2021). Consumption access and agglomeration: evidence from smartphone data. Technical report, National Bureau of Economic Research. 
Reichenberger, A. (2012). A comparison of 25 years of consumer expenditures by homeowners and renters.

Rosenthal, S. S., Strange, W. C., and Urrego, J. A. (2021). Jue insight: Are city centers losing their appeal? commercial real estate, urban spatial structure, and covid-19. Journal of Urban Economics, page 103381.

Salas-Olmedo, M. H., Moya-Gómez, B., García-Palomares, J. C., and Gutiérrez, J. (2018). Tourists' digital footprint in cities: Comparing big data sources. Tourism Management, 66:13-25.

Schaefer, M. and Tran, K. (2021). Airbnb, hotels, and localized competition. Available at SSRN.

Schiff, N. (2015). Cities and product variety: evidence from restaurants. Journal of Economic Geography, 15(6):1085-1123.

Shoval, N., McKercher, B., Ng, E., and Birenboim, A. (2011). Hotel location and tourist activity in cities. Annals of tourism research, 38(4):1594-1612.

Urquiaga, A. A., Sanz, I. M., Sanchez, J. R., et al. (2019). "no estamos tan mal como barcelona": análisis de la proliferación y regulación de las viviendas de uso turístico en madrid y barcelona. Boletín de la Asociación de Geógrafos Españoles, (83).

Valentin, M. (2021). Regulating short-term rental housing: Evidence from new orleans. Real Estate Economics, 49(1):152-186.

$\mathrm{Xu}, \mathrm{M}$. and $\mathrm{Xu}, \mathrm{Y} .(2021)$. What happens when airbnb comes to the neighborhood: The impact of home-sharing on neighborhood investment. Regional Science and Urban Economics, 88:103670.

Zervas, G., Proserpio, D., and Byers, J. W. (2017). The rise of the sharing economy: Estimating the impact of airbnb on the hotel industry. Journal of marketing research, 54(5):687-705. 


\section{Appendix}

\subsection{Intensive and extensive margin:}

The effect of Airbnb on the food and beverage employment can be decomposed as follows:

$$
\delta_{L} \times \Delta \text { Airbnb }=\underbrace{N_{t} \times \Delta S}_{\text {IntensiveMargin }}+\underbrace{\delta_{N} \times \Delta \text { Airbnb } \times\left(S_{t}+\Delta S\right)}_{\text {ExtensiveMargin }}
$$

where $\delta_{L}$ represents the effect of Airbnb on the employment (overall effect), $\Delta$ Airbnb, the variation in the number of Airbnb rooms, $N_{t}$, the number of food and beverage establishments, $\Delta S$, the variation in the establishment average employment, $\delta_{N}$, the effect of Airbnb on the number of food and beverage companies and $S_{t}$, the establishment average employment. The underlying assumption in the above decomposition is that either current restaurants and new restaurants vary the employment equally. We know all the parameters with the exception the variation in the establishment average employment, $\Delta S$. In turn, it can can be computed with the other parameters as follows:

$$
\Delta S=\frac{\Delta \text { Airbnb } \times\left(\delta_{L}-\delta_{N} \times S_{t}\right)}{N_{t}+\delta_{N} \times \Delta A i r b n b}
$$




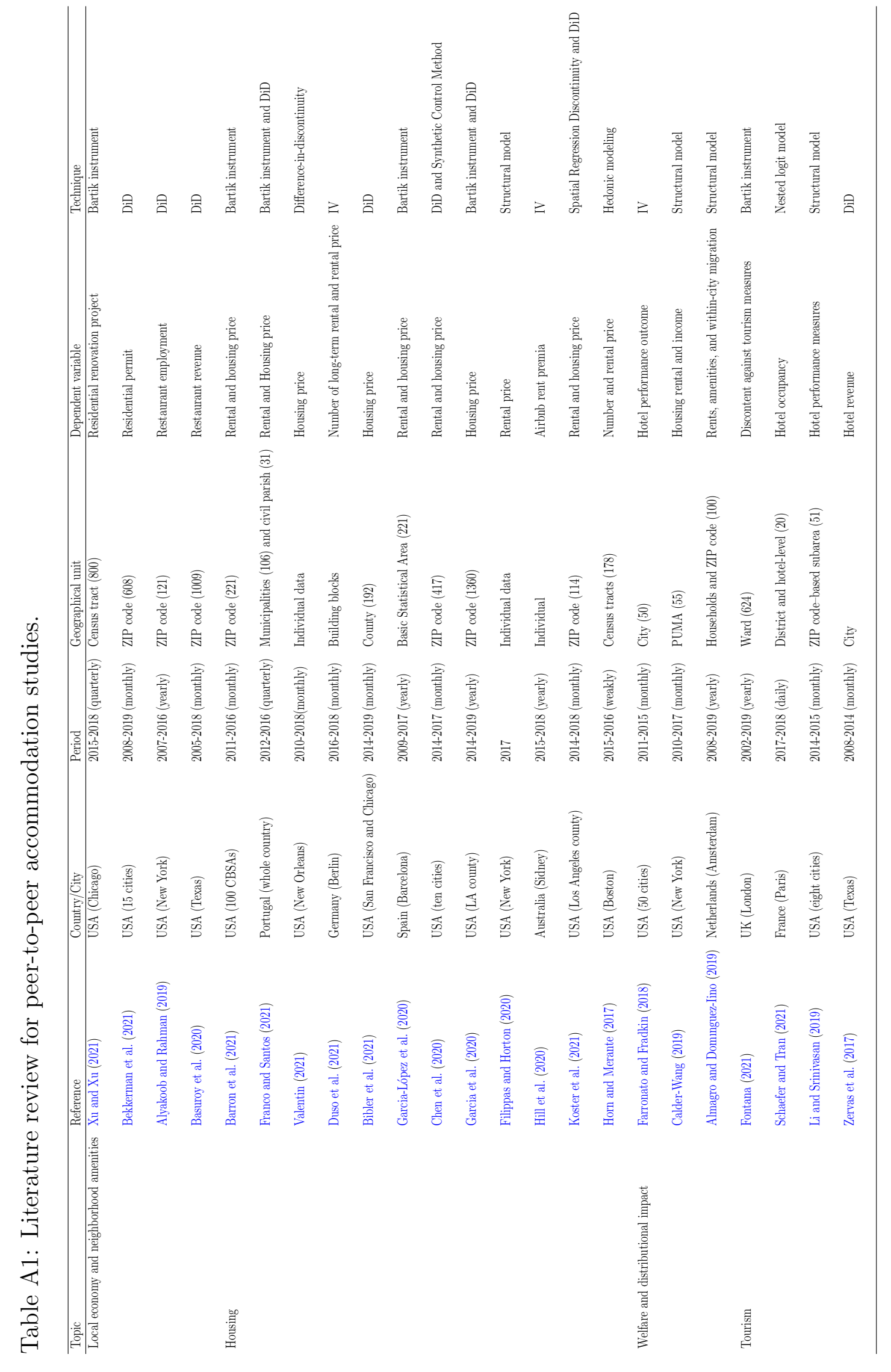




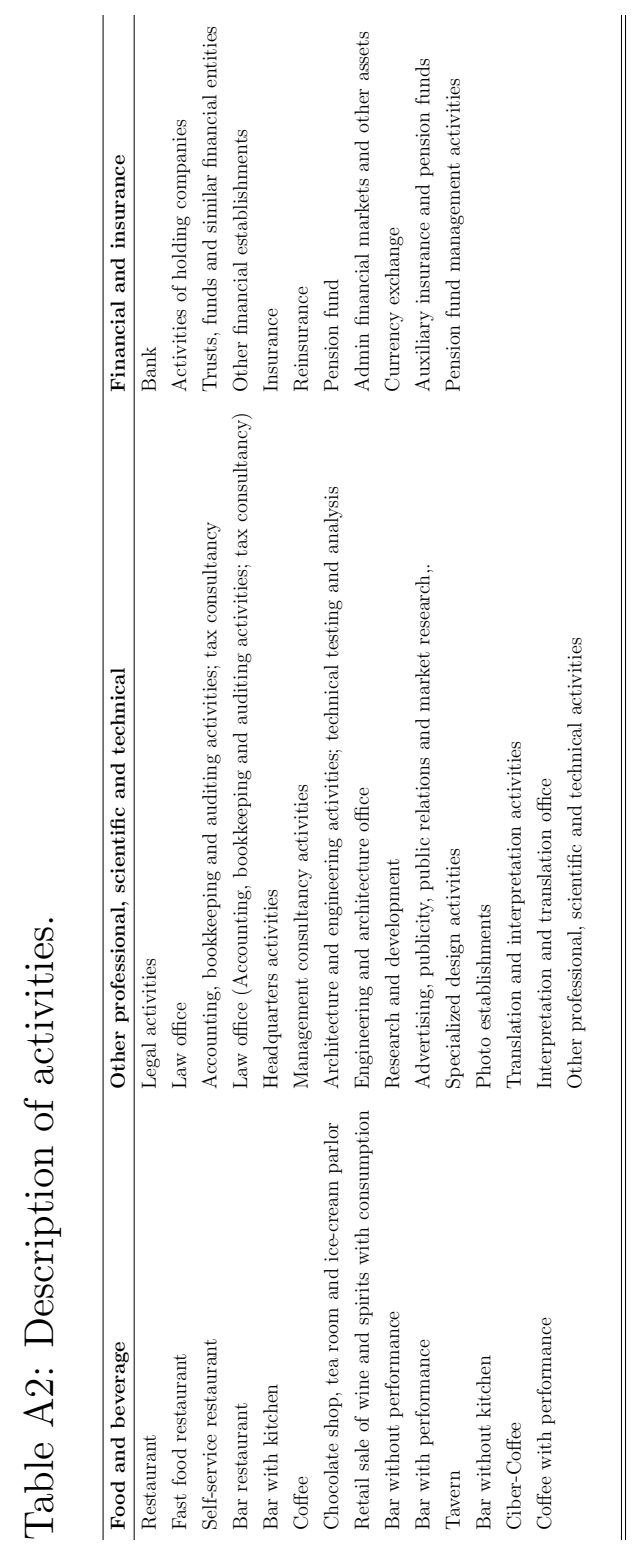


Figure A1: Spatial distribution of Airbnb rooms in April 2014.

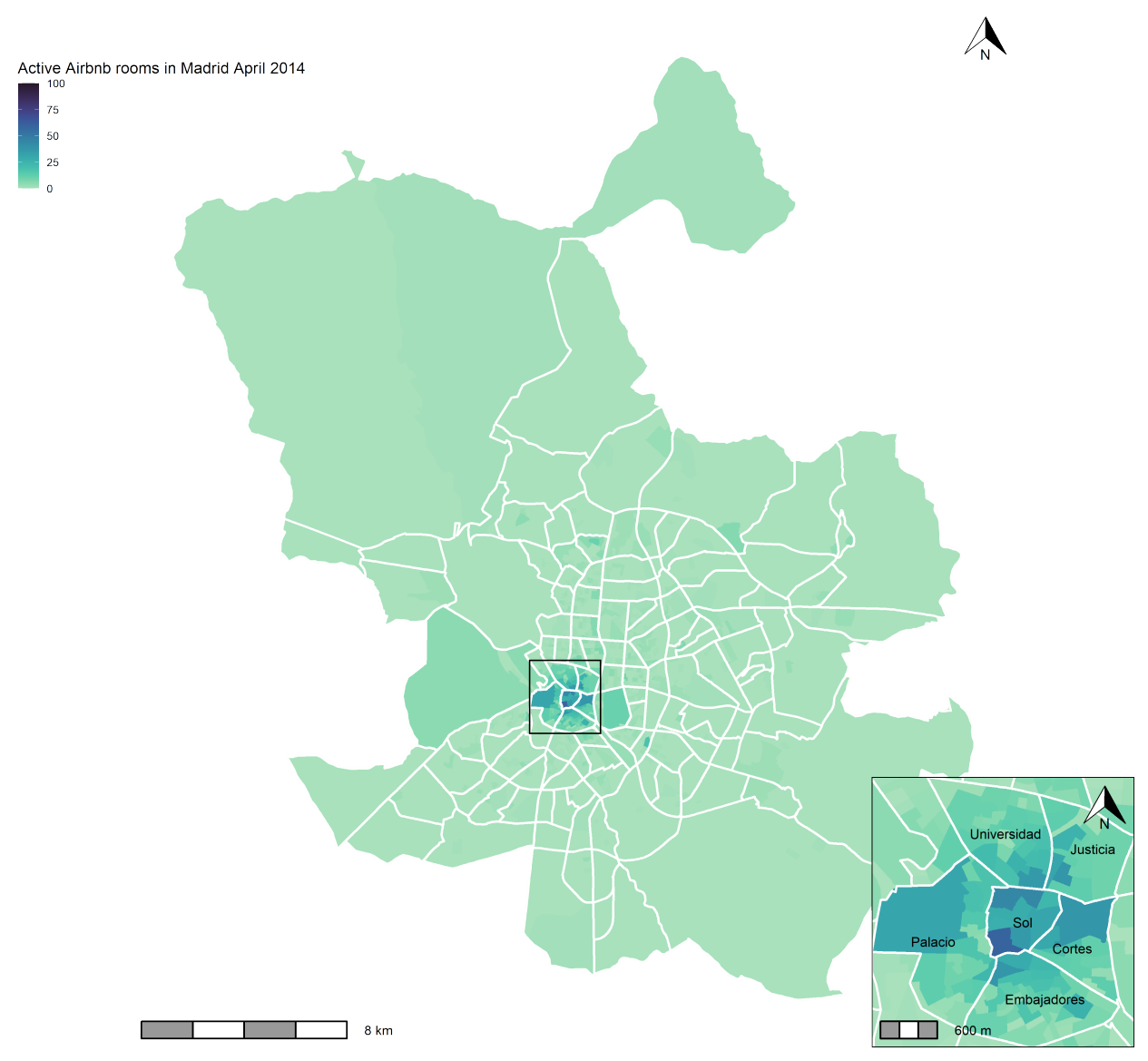

Notes: White lines delimit the administrative boundaries of neighborhoods, whereas the color intensity within neighborhoods reflects the number of Airbnb rooms in each census tracts. 
Figure A2: Spatial distribution of Airbnb rooms in April 2018.

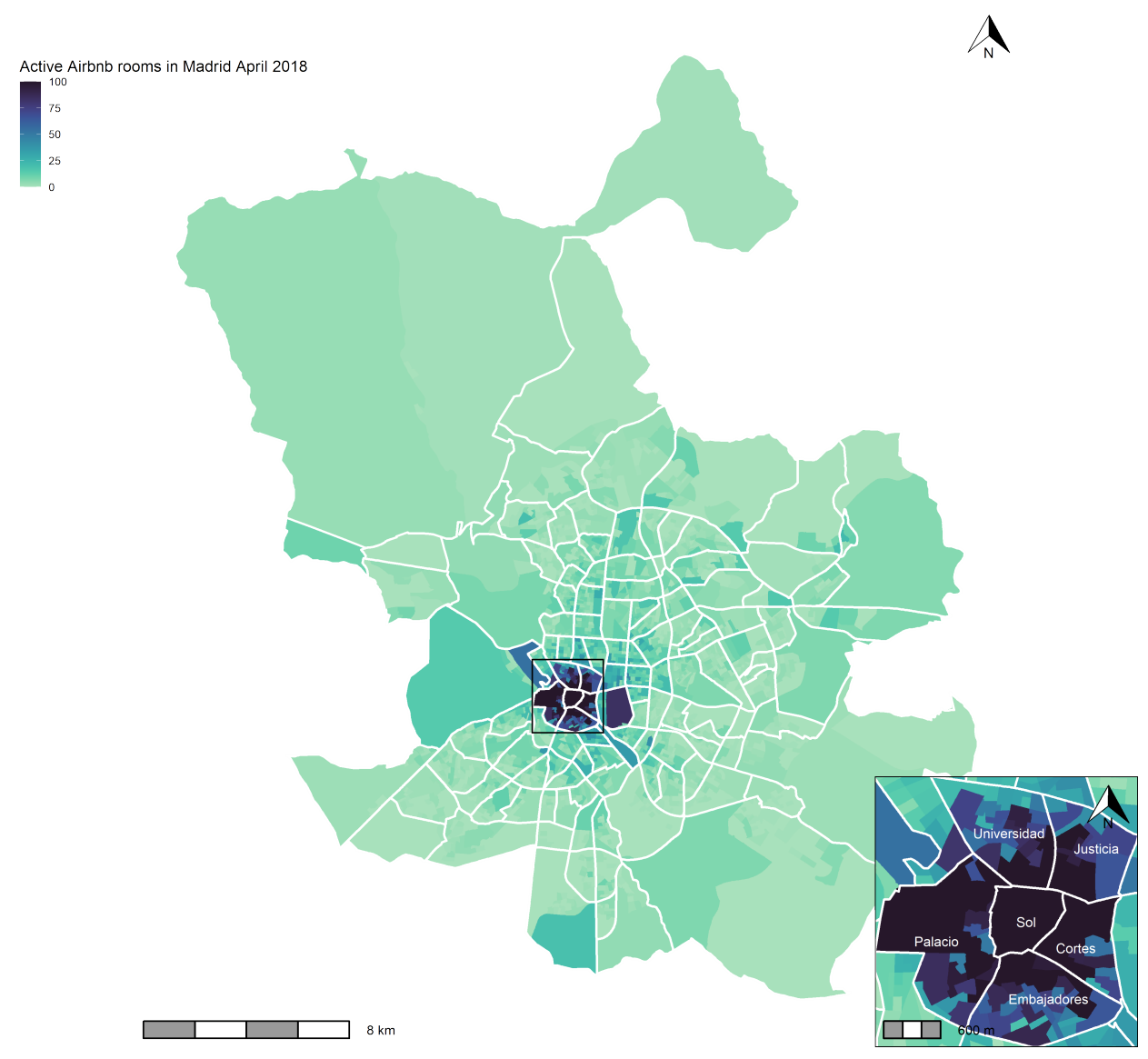

Notes: White lines delimit the administrative boundaries of neighborhoods, whereas the color intensity within neighborhoods reflects the number of Airbnb rooms in each census tracts. 
Table A3: The Impact of Airbnb on the number of Food and Beverage establishments (Log-Log and Poisson MODEL).

\begin{tabular}{|c|c|c|c|c|}
\hline \multirow{2}{*}{$\begin{array}{l}\text { Dependent Variables: } \\
\text { Model: }\end{array}$} & \multicolumn{2}{|c|}{$\log ($ Food and beverage establishments +1$)$} & \multicolumn{2}{|c|}{ Food and beverage establishments } \\
\hline & Whole sample (OLS) & Restricted sample (OLS) & Whole sample (Poisson) & Restricted sample (Poisson) \\
\hline \multicolumn{5}{|l|}{ Variables } \\
\hline \multirow[t]{2}{*}{$\log ($ Airbnb rooms +1$)$} & $0.0127^{* * *}$ & $0.0118^{* * *}$ & & \\
\hline & $(0.0034)$ & $(0.0034)$ & & \\
\hline \multirow[t]{2}{*}{ Airbnb rooms } & & & $0.0003^{*}$ & $0.0019^{* * *}$ \\
\hline & & & $(0.0001)$ & $(0.0007)$ \\
\hline \multirow[t]{2}{*}{ Population } & $0.0006^{* * *}$ & $0.0006^{* * *}$ & $0.0005^{* * *}$ & $0.0005^{* * *}$ \\
\hline & $\left(7.38 \times 10^{-5}\right)$ & $\left(7.4 \times 10^{-5}\right)$ & $\left(7.7 \times 10^{-5}\right)$ & $\left(7.82 \times 10^{-5}\right)$ \\
\hline \multirow[t]{2}{*}{ Foreign Population (\%) } & $-0.4339^{* * *}$ & $-0.4410^{* * *}$ & $-0.2509^{* *}$ & $-0.2750^{*}$ \\
\hline & $(0.0992)$ & $(0.1038)$ & $(0.1253)$ & $(0.1484)$ \\
\hline \multirow[t]{2}{*}{ Hotel rooms } & $5.72 \times 10^{-5}$ & $4.38 \times 10^{-5}$ & $9.21 \times 10^{-5}$ & $7.23 \times 10^{-5}$ \\
\hline & $(0.0001)$ & $(0.0001)$ & $(0.0001)$ & $(0.0001)$ \\
\hline \multicolumn{5}{|l|}{ Fixed-effects } \\
\hline Census tract & Yes & Yes & Yes & Yes \\
\hline Quarters & Yes & Yes & Yes & Yes \\
\hline \multicolumn{5}{|l|}{ Fit statistics } \\
\hline Observations & 41,800 & 39,691 & 41,800 & 39,691 \\
\hline $\mathrm{R}^{2}$ & 0.97987 & 0.97602 & 0.64035 & 0.55943 \\
\hline
\end{tabular}

Notes: Statistical significance at the 1,5 and $10 \%$ levels is indicated by $* * *, * *$ and $*$, respectively. Cluster standard errors at the census tract level. 
Table A4: Heterogeneous impact of Airbnb on the aCtivities Within the food and Beverage INDUSTRY (IV).

\begin{tabular}{lcccc}
\hline \hline $\begin{array}{l}\text { Dependent Variables: } \\
\text { Model: }\end{array}$ & $\begin{array}{c}\text { Restaurants } \\
\text { Restricted sample }\end{array}$ & $\begin{array}{c}\text { Bar } \\
\text { Restricted sample }\end{array}$ & $\begin{array}{c}\text { Coffee } \\
\text { Restricted sample }\end{array}$ & $\begin{array}{c}\text { Clubs } \\
\text { Restricted sample }\end{array}$ \\
\hline Variables & & & & \\
Airbnb rooms & $\mathbf{0 . 0 6 0 6}^{* *}$ & $\mathbf{0 . 0 3 3 5}$ & $\mathbf{0 . 0 5 0 3}^{* *}$ & $-\mathbf{0 . 0 0 8 4}$ \\
& $(0.0279)$ & $(0.0240)$ & $(0.0251)$ & $(0.0171)$ \\
Population & $0.0021^{* * *}$ & $0.0010^{* * *}$ & $0.0008^{* * *}$ & $0.0003^{* *}$ \\
& $(0.0004)$ & $(0.0002)$ & $(0.0002)$ & $(0.0002)$ \\
Foreign Population (\%) & -0.5550 & 0.3775 & -0.5510 & 0.2567 \\
& $(0.8435)$ & $(0.6964)$ & $(0.7421)$ & $(0.4992)$ \\
Hotel rooms & 0.0013 & 0.0019 & -0.0004 & -0.0011 \\
& $(0.0013)$ & $(0.0017)$ & $(0.0010)$ & $(0.0011)$ \\
\hline Fixed-effects & & & & Yes \\
Quarters & Yes & Yes & Yes & Yes \\
Census tract & Yes & Yes & Yes & 11,818 \\
\hline Fit statistics & & & & 23,142 \\
Observations & 28,006 & 35,321 & & C \\
\hline
\end{tabular}

Notes: Statistical significance at the 1, 5 and $10 \%$ levels is indicated by $* * * * *$ and $*$, respectively. Cluster standard errors at the census tract level. Shift-Share represents the interaction between the number of rented houses in 2011 and the worldwide Airbnb Google searches. Time trend and distance to the center interaction include in all specifications but not shown. 
Table A5: IV validity check.

\begin{tabular}{|c|c|}
\hline $\begin{array}{l}\text { Dependent Variable: } \\
\text { Model: }\end{array}$ & $\begin{array}{c}\text { Food and beverage establishments } \\
\text { Restricted sample }\end{array}$ \\
\hline \multicolumn{2}{|l|}{ Variables } \\
\hline Shift-Share & $\begin{array}{l}-3.03 \times 10^{-5} \\
\left(1.95 \times 10^{-5}\right)\end{array}$ \\
\hline Population & $\begin{array}{c}0.0033^{* * *} \\
(0.0009)\end{array}$ \\
\hline Foreign population $(\%)$ & $\begin{array}{l}-4.074^{*} \\
(2.395)\end{array}$ \\
\hline Hotel rooms & $\begin{array}{c}0.0140 \\
(0.0094)\end{array}$ \\
\hline \multicolumn{2}{|l|}{ Fixed-effects } \\
\hline Quarters & Yes \\
\hline Census tract & Yes \\
\hline \multicolumn{2}{|l|}{ Fit statistics } \\
\hline Observations & 6,365 \\
\hline $\begin{array}{l}\text { Notes: Statistical signific } \\
\text { indicated by } * * *, * * \text { and } * \\
\text { at the census tract level. } \\
\text { between the number of rer } \\
\text { Airbnb Google searches. } \\
\text { interaction include in all sp }\end{array}$ & $\begin{array}{l}\text { ance at the } 1,5 \text { and } 10 \% \text { levels is } \\
\text { respectively. Cluster standard errors } \\
\text { Shift-Share represents the interaction } \\
\text { ted houses in } 2011 \text { and the worldwide } \\
\text { Time trend and distance to the center } \\
\text { ecifications but not shown. }\end{array}$ \\
\hline
\end{tabular}




\section{MTT $\begin{aligned} & \text { SCHOOL } \\ & \text { FOR ADVANCED }\end{aligned}$ STUDIES LUCCA}

2022 @ IMT School for Advanced Studies, Lucca

Piazza San ponziano 6, 5100 Lucca, Italy. www.imtlucca.it 